\title{
Nested-grid simulation of mercury over North America
}

\author{
Y. Zhang ${ }^{1}$, L. Jaeglé ${ }^{1}$, A. van Donkelaar ${ }^{2}$, R. V. Martin ${ }^{2,3}$, C. D. Holmes ${ }^{4}$, H. M. Amos ${ }^{5}$, Q. Wang ${ }^{6}$, R. Talbot ${ }^{7}$, \\ R. Artz $^{8}$, S. Brooks ${ }^{8}$, W. Luke ${ }^{8}$, T. M. Holsen ${ }^{9}$, D. Felton ${ }^{10}$, E. K. Miller ${ }^{11}$, K. D. Perry ${ }^{12}$, D. Schmeltz ${ }^{13}$, A. Steffen ${ }^{14}$, \\ R. Tordon ${ }^{14}$, P. Weiss-Penzias ${ }^{15}$, and R. Zsolway ${ }^{16}$ \\ ${ }^{1}$ Department of Atmospheric Sciences, University of Washington, Seattle, WA, USA \\ ${ }^{2}$ Department of Physics and Atmospheric Science, Dalhousie University, Halifax, NS, Canada \\ ${ }^{3}$ Harvard Smithsonian Center for Astrophysics, Cambridge, Massachusetts, USA \\ ${ }^{4}$ Department of Earth System Sciences, University of California, Irvine, CA, USA \\ ${ }^{5}$ Department of Earth and Planetary Sciences, Harvard University, Cambridge MA, USA \\ ${ }^{6}$ School of Engineering and Applied Sciences, Harvard University, Cambridge MA, USA \\ ${ }^{7}$ Department of Earth and Atmospheric Sciences, University of Houston, Houston, TX, USA \\ ${ }^{8}$ NOAA Air Resources Laboratory, Silver Spring, MD, USA \\ ${ }^{9}$ Department of Civil and Environmental Engineering, Clarkson University, Potsdam, NY, USA \\ ${ }^{10} \mathrm{New}$ York State Department of Environmental Conservation, Division of Air Resources, Albany, NY, USA \\ ${ }^{11}$ Ecosystems Research Group, Norwich, VT, USA \\ ${ }^{12}$ Department of Atmospheric Sciences, University of Utah, Salt Lake City, UT, USA \\ ${ }^{13}$ Office of Atmospheric Programs, US Environmental Protection Agency, Washington DC, USA \\ ${ }^{14}$ Environment Canada, Air Quality Research Division, Toronto, Ontario, Canada \\ ${ }^{15}$ Department of Microbiology and Environmental Toxicology, University of California, Santa Cruz, CA, USA \\ ${ }^{16}$ Division of Environmental Regulation, Bureau of Air Quality Monitoring, New Jersey Department of Environmental \\ Protection, Trenton, NJ, USA
}

Correspondence to: Y. Zhang (yanxuz@atmos.washington.edu)

Received: 20 December 2011 - Published in Atmos. Chem. Phys. Discuss.: 26 January 2012

Revised: 19 June 2012 - Accepted: 28 June 2012 - Published: 16 July 2012

\begin{abstract}
We have developed a new nested-grid mercury $(\mathrm{Hg})$ simulation over North America with a $1 / 2^{\circ}$ latitude by $2 / 3^{\circ}$ longitude horizontal resolution employing the GEOSChem global chemical transport model. Emissions, chemistry, deposition, and meteorology are self-consistent between the global and nested domains. Compared to the global model ( $4^{\circ}$ latitude by $5^{\circ}$ longitude), the nested model shows improved skill at capturing the high spatial and temporal variability of $\mathrm{Hg}$ wet deposition over North America observed by the Mercury Deposition Network (MDN) in 20082009. The nested simulation resolves features such as higher deposition due to orographic precipitation, land/ocean contrast and and predicts more efficient convective rain scavenging of $\mathrm{Hg}$ over the southeast United States. However, the nested model overestimates $\mathrm{Hg}$ wet deposition over the Ohio River Valley region (ORV) by $27 \%$. We modify anthropogenic emission speciation profiles in the US EPA Na-
\end{abstract}

tional Emission Inventory (NEI) to account for the rapid inplume reduction of reactive to elemental $\mathrm{Hg}$ (IPR simulation). This leads to a decrease in the model bias to $-2.3 \%$ over the ORV region. Over the contiguous US, the correlation coefficient $(r)$ between MDN observations and our IPR simulation increases from 0.60 to 0.78 . The IPR nested simulation generally reproduces the seasonal cycle in surface concentrations of speciated $\mathrm{Hg}$ from the Atmospheric Mercury Network (AMNet) and Canadian Atmospheric Mercury Network (CAMNet). In the IPR simulation, annual mean gaseous and particulate-bound $\mathrm{Hg}$ (II) are within $140 \%$ and $11 \%$ of observations, respectively. In contrast, the simulation with unmodified anthropogenic $\mathrm{Hg}$ speciation profiles overestimates these observations by factors of 4 and 2 for gaseous and particulate-bound $\mathrm{Hg}(\mathrm{II})$, respectively. The nested model shows improved skill at capturing the horizontal variability of Hg observed over California during the ARCTAS aircraft 
campaign. The nested model suggests that North American anthropogenic emissions account for 10-22\% of $\mathrm{Hg}$ wet deposition flux over the US, depending on the anthropogenic emissions speciation profile assumed. The modeled percent contribution can be as high as $60 \%$ near large point sources in ORV. Our results indicate that the North American anthropogenic contribution to dry deposition is $13-20 \%$.

\section{Introduction}

Mercury $(\mathrm{Hg})$ is a ubiquitous trace metal in the atmosphere and is emitted by both natural (Mason, 2009) and anthropogenic sources such as coal combustion, waste incineration and gold mining (Streets et al., 2009; Pacyna et al., 2010; Pirrone et al., 2009). Anthropogenic emissions of Hg occur in the long-lived elemental form $(\operatorname{Hg}(0))$, but also as shortlived oxidized mercury $(\mathrm{Hg}(\mathrm{II}))$ and particulate-bound mercury $(\mathrm{Hg}(\mathrm{P}))$. Both $\mathrm{Hg}(\mathrm{II})$ and $\mathrm{Hg}(\mathrm{P})$ are rapidly removed by wet and dry deposition near source regions, while $\mathrm{Hg}(0)$ can be transported on global scales. $\mathrm{Hg}(0)$ is then deposited over remote areas via dry deposition of $\mathrm{Hg}(0)$ itself or through oxidation to $\mathrm{Hg}(\mathrm{II})$, followed by its subsequent deposition (Lindberg et al., 2007). Once in aquatic ecosystems, Hg may be converted to the neurotoxin methylmercury, which can bioaccumulate in the food chain (Morel et al., 1998). Human exposure occurs via consumption of fish and seafood (Mergler et al., 2007; Sunderland, 2007). Because of its adverse effects on human health and the environment, $\mathrm{Hg}$ pollution is being actively regulated at national levels and there are now ongoing international negotiations to achieve a global legally-binding agreement for $\mathrm{Hg}$ emission reductions (UNEP, 2012).

A number of global $\mathrm{Hg}$ models have been developed to interpret observations, test chemical mechanisms and constrain the global $\mathrm{Hg}$ budget (e.g. GISS-CTM: Shia et al., 1999; GEOS-Chem: Selin et al., 2007; GRAHM: Dastoor and Larocque, 2004). However, these models often have coarse horizontal resolution $(\sim 200-1000 \mathrm{~km})$ and thus lack the resolution needed for detailed evaluation at the regional scale. Regional models have higher resolution over a limited domain, which is necessary to resolve the observed high spatial variability in $\mathrm{Hg}$ deposition (Keeler et al., 2006; Dvonch et al., 2005). A disadvantage of these models is their sensitivity to assumed initial and lateral boundary conditions. One way to solve this issue is to use a global model to provide initial and boundary conditions in a multi-scale modeling approach (Bash, 2010; Bullock et al., 2008; Lin and Tao, 2003; Pan et al., 2007; Seigneur et al., 2001; Vijayaraghavan et al., 2008). A significant problem with this approach, however, is that the regional and global models often use different assumptions about $\mathrm{Hg}$ emissions, chemistry, deposition, and meteorology. Use of different global models to define boundary conditions leads to large variations in regional patterns of atmospheric $\mathrm{Hg}$ concentrations, as well as wet and dry deposition (Bullock et al., 2008, 2009; Pongprueksa et al., 2008).

In this paper, we describe the development of a new nested North American $\mathrm{Hg}$ simulation with higher resolution $\left(1 / 2^{\circ}\right.$ latitude by $2 / 3^{\circ}$ longitude) in the GEOS-Chem model. This North American window is imbedded in a lower resolution $\left(4 \times 5^{\circ}\right)$ global GEOS-Chem simulation. Chemistry, deposition, emissions, and meteorology are self-consistent between the nested and global domains. The horizontal resolution of the nested-grid domain $(\sim 50 \mathrm{~km})$ is comparable to that used in many regional scale $\mathrm{Hg}$ models (for example, most published work with CMAQ uses $36 \mathrm{~km}$ ), however the vertical resolution is much higher (surface to $10 \mathrm{hPa}$ : 14 vertical levels in CMAQ versus 40 levels in GEOS-Chem).

The aims of this study are to (1) evaluate the GEOS-Chem nested-grid $\mathrm{Hg}$ simulation by comparisons to observations of wet deposition and atmospheric concentrations over North America; (2) examine the impact of resolution $\left(4 \times 5^{\circ}\right.$ versus $\left.1 / 2 \times 2 / 3^{\circ}\right)$ and partitioning of anthropogenic North American emissions on model predictions; (3) assess the origin of wet deposition over the US in the nested-grid GEOS-Chem model and quantify the relative impacts of domestic versus global emissions on deposition.

\section{Model description}

\subsection{GEOS-Chem global Hg simulation}

GEOS-Chem is a global chemical transport model (Bey et al., 2001), which is driven by assimilated meteorological observations from the NASA Goddard Earth Observing System (GEOS). The most recent meteorological fields (GEOS5) have a spatial resolution of $1 / 2^{\circ}$ latitude by $2 / 3^{\circ}$ longitude, with 72 hybrid eta levels from the surface to $0.01 \mathrm{hPa}$. The lowest $2 \mathrm{~km}$ are resolved with 13 layers. For input to the GEOS-Chem global simulation, these fields are degraded horizontally to $4 \times 5^{\circ}$ and vertically to 47 levels due to computational limitations. We use GEOS-Chem version v9-0102 in this paper (http://acmg.seas.harvard.edu/geos/).

The GEOS-Chem atmospheric Hg simulation is described and evaluated in Selin et al. (2007), with recent updates in $\mathrm{Hg}$ chemistry and deposition by Holmes et al. (2010) and Amos et al. (2012). The model includes two atmospheric mercury species: elemental $\mathrm{Hg}(\mathrm{Hg}(0))$ and divalent $\mathrm{Hg}(\mathrm{Hg}(\mathrm{II}))$. Anthropogenic $\mathrm{Hg}$ emissions are from the Global Emission Inventory Activity (GEIA) 2005 inventory of Pacyna et al. (2010), with a native spatial resolution of $0.5 \times 0.5^{\circ}$. This inventory provides anthropogenic emissions for $\mathrm{Hg}(0), \mathrm{Hg}(\mathrm{II})$, and $\mathrm{Hg}(\mathrm{P})$. We combine both $\mathrm{Hg}(\mathrm{II})$ and $\mathrm{Hg}(\mathrm{P})$ emissions into our single $\mathrm{Hg}(\mathrm{II})$ tracer. Over the US and Canada the GEIA anthropogenic inventory is overwritten with more recent regional inventories (see Sect. 2.2). The resulting global anthropogenic emissions are $1900 \mathrm{Mg} \mathrm{a}^{-1}$. Natural sources account for a total of 
$6600 \mathrm{Mg} \mathrm{a}^{-1}$, including $4900 \mathrm{Mg} \mathrm{a}^{-1}\left(3000 \mathrm{Mg} \mathrm{a}^{-1}\right.$ net evasion) from air-sea exchange (Strode et al., 2007; Soerensen et al., 2010b), $1400 \mathrm{Mg} \mathrm{a}^{-1}$ from land (Selin et al., 2008; Amos et al., 2012), $220 \mathrm{Mg} \mathrm{a}^{-1}$ from open fire biomass burning in 2008-2009 (Global Fire Emission Database version 2, assuming a $\mathrm{Hg} / \mathrm{CO}$ emission ratio of $100 \mathrm{nmol} \mathrm{mol}^{-1}$ as suggested by Holmes et al., 2010), and $140 \mathrm{Mg} \mathrm{a}^{-1}$ from snow re-emissions (Holmes et al., 2010).

Considerable uncertainty remains on the $\mathrm{Hg}(0)$ oxidation mechanisms and their kinetics (Gårdfeldt et al., 2001; Calvert and Lindberg, 2005; Si and Ariya, 2008). In the original GEOS-Chem simulation, Selin et al. (2007) assumed OH and $\mathrm{O}_{3}$ to be the main oxidants for $\mathrm{Hg}(0)$. They also included aqueous-phase photochemical reduction of $\mathrm{Hg}(\mathrm{II})$, proportional to $\mathrm{OH}$ concentrations and scaled to match constraints on $\mathrm{Hg}$ lifetime and seasonal variation. However, work by Calvert and Lindberg (2005) and Hynes et al. (2009) suggest that the oxidation of $\mathrm{Hg}(0)$ by $\mathrm{OH}$ and $\mathrm{O}_{3}$ is too slow to be significant in the atmosphere. Therefore, Holmes et al. $(2006,2010)$ updated GEOS-Chem to use $\mathrm{Br}$ atoms as the sole oxidant for $\mathrm{Hg}(0)$, with kinetic parameters from Donohoue et al. (2006), Goodsite et al. (2004) and Balabanov et al. (2005). They found that $\mathrm{Hg}+\mathrm{Br}$ chemistry, like the previous $\mathrm{Hg}+\mathrm{OH} / \mathrm{O}_{3}$ chemistry, can reproduce most mercury observations, with some improved prediction of the interhemispheric gradient in total gaseous mercury (TGM) concentrations and the TGM concentrations in polar regions. Holmes et al. (2010) included aqueous-phase photochemical reduction of $\mathrm{Hg}(\mathrm{II})$, scaled to $\mathrm{NO}_{2}$ photolysis. We follow the Holmes et al. (2010) chemical mechanism in this work.

The global bromine fields are described in Holmes et al. (2010), and are based on 3-D monthly archived Br concentrations from the p-TOMCAT model in the troposphere (Yang et al., 2005) and from NASA's Global Modeling Initiative model in the stratosphere (Strahan et al., 2007). The resulting $\mathrm{BrO}$ column concentrations are consistent with satellite observations (Richter et al., 2002; Sioris et al., 2006). Over polar regions, elevated concentrations of $\mathrm{Br}$ atoms can be produced by refreezing of open leads during spring (Simpson et al., 2007), leading to so-called bromine explosion events and rapid depletion of $\operatorname{Hg}(0)$ (Steffen et al., 2008). This process is parameterized in GEOS-Chem by assuming $5 \mathrm{ppt} \mathrm{BrO}$ in the polar boundary layer during springtime over areas with sea ice, sunlight, stable conditions and temperatures below $268 \mathrm{~K}$ (Holmes et al., 2010).

We assume that $\mathrm{Hg}$ (II) is in equilibrium between gas and particulate phase at all times. The partitioning between these two phases is based on the empirical relationship derived by Amos et al. (2012) and is calculated as a function of temperature and monthly mean fine particulate matter concentrations. This empirical relationship was obtained from longterm observations of gas phase $\mathrm{Hg}$ (II) (reactive gaseous mercury, RGM) and particulate-bound $\mathrm{Hg}$ (II) (particulate bound mercury, PBM) at five sites over North America (Edgerton et al., 2006; Graydon et al., 2008; Lyman and Gustin, 2009; Rutter and Schauer, 2007; Sigler et al., 2009).

GEOS-Chem simulates wet scavenging of $\mathrm{Hg}$ (II) and dry deposition of $\mathrm{Hg}(0)$ and $\mathrm{Hg}(\mathrm{II})$ following the scheme of Liu et al. (2001) and the resistance-in-series scheme of Wesely (1989), respectively. We assume complete retention of $\mathrm{Hg}$ (II) during freezing of supercooled water in mixed-phase clouds, but no scavenging during vapor condensation to cloud ice (Holmes et al., 2010; Wang et al., 2011). Belowcloud scavenging by snow is included only for $\mathrm{Hg}(\mathrm{II})$ in the aerosol phase (Holmes et al., 2010; Amos et al., 2012). The loss of $\mathrm{Hg}$ (II) via uptake onto sea-salt aerosol and subsequent deposition in the marine boundary layer is also included in this study (Holmes et al., 2009, 2010).

\subsection{Nested-grid $\mathrm{Hg}$ simulation}

We have implemented a new nested-grid capability with higher resolution in the GEOS-Chem $\mathrm{Hg}$ simulation. We use results from the global $\left(4 \times 5^{\circ}\right) \mathrm{Hg}$ simulation as initial and boundary conditions for a nested-grid simulation over the North American domain (defined as $10-70^{\circ} \mathrm{N}$ and $40-140^{\circ} \mathrm{W}$ ). The nested model is driven by GEOS5 meteorological fields at their native horizontal resolution $\left(1 / 2 \times 2 / 3^{\circ}\right)$. Both the nested and global models use the same vertical resolution. This one-way nesting approach was first developed in GEOS-Chem by Wang et al. (2004a, b) to examine $\mathrm{CO}$ and $\mathrm{NO}_{x}$ variability over Asia, and has also been applied to understand ozone and aerosol chemistry over North America (Fiore et al., 2005; Li et al., 2005; Park et al., 2006). These simulations used an earlier version of the GEOS fields (GEOS-3) with a native resolution of $1 \times 1^{\circ}$. More recently, Chen et al. (2009) updated the nested-grid CO simulation over Asia to use the newest GEOS-5 data, allowing for higher resolution. Chen et al. (2009) found that the higher spatial resolution allows for more efficient advectionrelated ventilation of the lower atmosphere and can better resolve frontal lifting. The nested model can also resolve the variability of emission densities over individual cities.

We first conducted a global $4 \times 5^{\circ}$ resolution simulation (referred to as the global model) for 2004-2009, archiving tracer mixing ratios of $\mathrm{Hg}(0)$ and $\mathrm{Hg}(\mathrm{II})$ at the lateral boundaries of the nested model every $3 \mathrm{~h}$. The nested model was then run for 2008-2009 using these 3-hourly lateral mixing ratios, with an initial spin-up time of one month starting with initial conditions from the global model. Figure 1 (top panels) compares the meteorological data driving the global and nested models, using precipitation as an example. The nested model resolves many fine features in the spatial distribution of precipitation which are lost by horizontal averaging at the $4 \times 5^{\circ}$ resolution. In particular, orographic precipitation is identifiable in the mountain ranges along the west coast of North America, the Rocky Mountains and the Appalachian Mountains. In addition, details in precipitation over the Gulf of Mexico and Northwest Atlantic are more clearly apparent. 

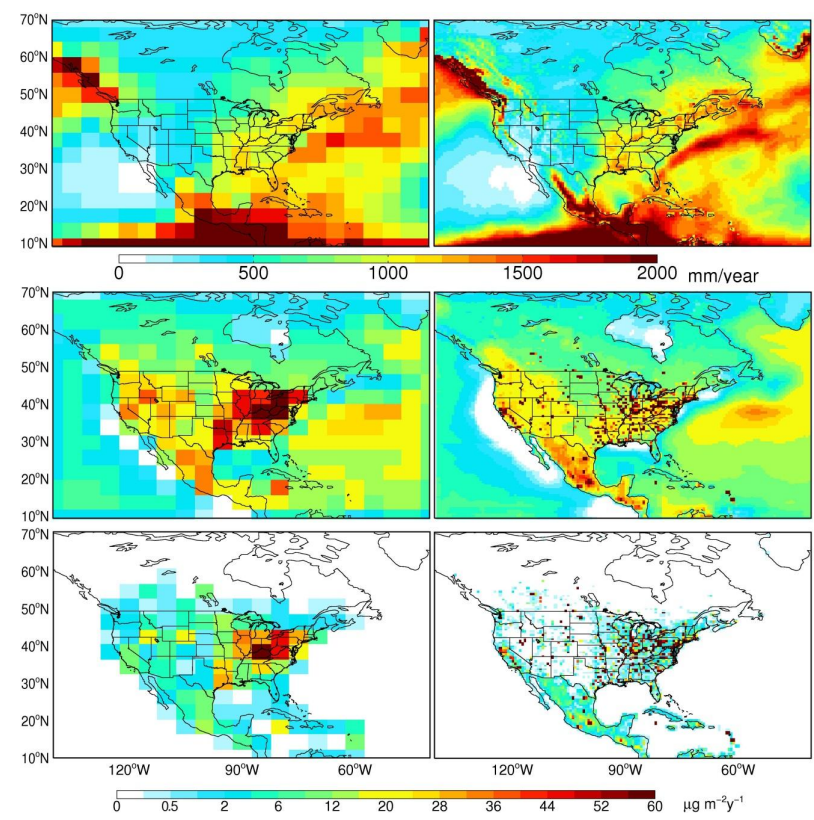

Fig. 1. Comparison between the global $\left(4 \times 5^{\circ}\right.$, left column $)$ and nested $\left(1 / 2 \times 2 / 3^{\circ}\right.$, right column $)$ models over the North American domain. Top row: total surface precipitation in 2008. Middle row: total $\mathrm{Hg}$ emissions including natural and anthropogenic sources (IPR simulation). Bottom row: anthropogenic $\mathrm{Hg}$ emissions based on the EPA NEI 2005 inventory for the US, the NPRI 2005 inventory for Canada, and the GEIA2005 inventory for Mexico.

Anthropogenic $\mathrm{Hg}$ emissions in the US were obtained from the 2005 EPA NEI inventory (NEI05, http://www.epa. gov/ttn/chief/eiinformation.html). The NEI05 inventory includes $\mathrm{Hg}$ emissions from point, nonpoint (area), and mobile sources within different sectors. We assign the point source $\mathrm{Hg}$ emissions into the corresponding model grid box according to geographic location. For nonpoint and mobile sources, the county-specific $\mathrm{Hg}$ emissions were distributed into the model grid system with the surrogate data provided by the EPA (http://www.epa.gov/ttn/chief/emch/ spatial/newsurrogate.html). Mercury speciation profiles are reported for all coal-fired power plants (CFPPs) individually in the NEI05 inventory. For other sources, we use the source-specific emission profiles reported in the inventory. As in the global model, we merge $\mathrm{Hg}(\mathrm{II})$ and $\mathrm{Hg}(\mathrm{P})$ emissions into the $\mathrm{Hg}$ (II) tracer in the nested model. Over the continental US, the 2005 anthropogenic $\mathrm{Hg}$ emissions are $111.3 \mathrm{Mg} \mathrm{a}^{-1}$ (61.5 $\left.\mathrm{Mg} \mathrm{a}^{-1} \mathrm{Hg}(0), 49.8 \mathrm{Mg} \mathrm{a}^{-1} \mathrm{Hg}(\mathrm{II})\right)$. Point sources dominate these emissions with $104.7 \mathrm{Mg} \mathrm{a}^{-1}$, while nonpoint and mobile sources emit $5.5 \mathrm{Mg} \mathrm{a}^{-1}$ and $1.1 \mathrm{Mg} \mathrm{a}^{-1}$, respectively. CFPPs account for $49 \%$ of the total national anthropogenic emissions. For simplicity, we do not take into account the seasonal, weekly, and diurnal variations in $\mathrm{Hg}$ anthropogenic emissions reported in the NEI inventory.

Over Canada, we used emissions from the Canadian National Pollutant Release Inventory 2005 (NPRI05, http:// www.ec.gc.ca/inrp-npri/). The point sources in the NPRI05 inventory were processed in a similar manner as those in NEI2005, and the area and mobile sources were spatially allocated over the model grid using population as the surrogate. The total Canadian anthropogenic $\mathrm{Hg}$ emissions are 6.2 $\mathrm{Mg} \mathrm{a}^{-1}$ (3.8 $\left.\mathrm{Mg} \mathrm{a}^{-1} \mathrm{Hg}(0), 2.4 \mathrm{Mg} \mathrm{a}^{-1} \mathrm{Hg}(\mathrm{II})\right)$. Anthropogenic emissions from Mexico in the nested model domain are directly gridded from the GEIA emission inventory, and account for $27.9 \mathrm{Mg} \mathrm{a}^{-1}$.

Observations collected at ground-based sites 7-15 km downwind of power plants in the Southeastern US show that $\mathrm{Hg}(\mathrm{II})$ accounts for only 8-21\% of total $\mathrm{Hg}$ (Edgerton et al., 2006; Weiss-Penzias et al., 2011). This is a factor of $\sim 3-$ 5 lower than the $\mathrm{Hg}(\mathrm{II})$ fraction measured in CFPPs stacks (40-70\% $\mathrm{Hg}(\mathrm{II})$ ). From airborne measurements downwind of a CFPP, ter Schure et al. (2011) show that reduction occurs in CFPP plumes much faster than in the background atmosphere. Lohman et al. (2006) speculated that this inplume conversion of $\mathrm{Hg}$ (II) to $\mathrm{Hg}(0)$ could be due to reduction by $\mathrm{SO}_{2}$. Vijayaraghavan et al. (2008) incorporated this rapid reduction into a regional $\mathrm{Hg}$ model with an explicit treatment of stack plume evolution. They found that this improved model performance for wet deposition in the Northeast US. In order to consider this process in our study, we modified the CFPPs $\mathrm{Hg}$ emission partitioning from the original $56.8 \% \mathrm{Hg}(0)$ and $43.2 \% \mathrm{Hg}(\mathrm{II})$ in the NEI and NPRI inventories to $89.2 \% \mathrm{Hg}(0)$ and $10.8 \% \mathrm{Hg}(\mathrm{II})$ over the US and Canada. This effectively assumes that $75 \%$ of the CFPPs $\mathrm{Hg}(\mathrm{II})$ emissions are reduced to $\mathrm{Hg}(0)$ in the immediate vicinity of power plants, consistent with the Edgerton et al. (2006) and Weiss-Penzias et al. (2011). The NEI inventory assumes relatively high portions of $\mathrm{Hg}$ (II) in the emission profiles for waste incineration $(22 \% \mathrm{Hg}(0), 78 \% \mathrm{Hg}(\mathrm{II}))$. Because of the high $\mathrm{SO}_{2}$ concentration from stacks of waste incinerator (Psomopoulos et al., 2009; Stevenson, 2002), we assume a similar in-plume reduction process happens to this source, and reduce the $\mathrm{Hg}$ (II) content from waste incineration emissions by $75 \%$, resulting in a speciation profile of $80.5 \% \mathrm{Hg}(0)$ and $19.5 \% \mathrm{Hg}(\mathrm{II})$. We note that no measurements of $\mathrm{Hg}$ speciation in waster incinerator plumes have been reported, so this assumption remains speculative.

With these speciation profile changes, the resulting anthropogenic $\mathrm{Hg}$ emissions in North America are: $121 \mathrm{Mg} \mathrm{a}^{-1}$ $\mathrm{Hg}(0)$ and $25 \mathrm{Mg} \mathrm{a}^{-1} \mathrm{Hg}(\mathrm{II})$. We will refer to simulations with this inventory as in-plume reduction (IPR) simulations and contrast them to our standard (STD) simulations with the original anthropogenic $\mathrm{Hg}$ speciation $\left(87 \mathrm{Mg} \mathrm{a}^{-1}\right.$ $\mathrm{Hg}(0)$, and $59 \mathrm{Mg} \mathrm{a}^{-1} \mathrm{Hg}(\mathrm{II})$ over North America). To have self-consistent global and North American anthropogenic inventories in the IPR simulation, we also modified the $\mathrm{Hg}(0): \mathrm{Hg}(\mathrm{II})$ speciation profile for fossil fuel combustion in Pacyna et al. (2010) from $50: 50 \%$ to $87.5: 12.5 \%$.

Figure 1 (bottom panels) shows the spatial distribution of total anthropogenic $\mathrm{Hg}$ emissions over North America. These are held constant over the 2008-2009 simulation period. 
Emissions are highest in coal combustion regions in the Ohio River Valley and eastern Texas. Some individual point sources such as power plants and municipal waste incinerators are distinct in the nested model, whereas they are averaged over much larger regions in the global model.

Within the nested model domain, geogenic emissions $\left(60 \mathrm{Mg} \mathrm{a}^{-1}\right)$ and legacy soil emissions $\left(130 \mathrm{Mg} \mathrm{a}^{-1}\right)$ are interpolated to finer resolution from the global model. Other emissions are calculated interactively within the nested model using the same algorithms as the global model, including biomass burning $\left(10 \mathrm{Mg} \mathrm{a}^{-1}\right)$, oceans $\left(280 \mathrm{Mg} \mathrm{a}^{-1}\right)$, soil $\left(35 \mathrm{Mg} \mathrm{a}^{-1}\right)$, and snow $\left(12 \mathrm{Mg} \mathrm{a}^{-1}\right)$. Figure 1 (middle panels) shows the total $\mathrm{Hg}$ emission from both anthropogenic and natural sources. Geogenic $\mathrm{Hg}$ emissions in the model are a significant source in western North America along a band stretching from southwest Canada to Mexico (Gustin et al., 1997). The modeled re-emissions from soil, snow and ocean generally follow the spatial pattern of anthropogenic emissions. The modeled soil, snow and ocean emissions strengths depend on meteorology, but vary by less than $15 \%$ over these two years.

The monthly concentrations of $\mathrm{Br}, \mathrm{BrO}$ and $\mathrm{OH}$ radicals in the nested model are obtained by interpolating fields used in the global model. To evaluate the contribution from North American anthropogenic sources, we conducted a sensitivity study with primary anthropogenic $\mathrm{Hg}$ emissions from the US, Canada and Mexico turned off. We will refer to this simulation as the "background" simulation.

\section{Model evaluation}

We evaluated the nested-grid model against a series of observations in North America including $\mathrm{Hg}$ wet deposition from the Mercury Deposition Network (MDN, 2011), near surface $\mathrm{Hg}$ concentrations from the Atmospheric Mercury Network (AMNet, 2009) and from the Canadian Atmospheric Mercury Measurement Network (CAMNet, 2011), and tropospheric $\mathrm{Hg}$ concentrations observed during the ARCTAS aircraft campaign (Mao et al., 2011). We will also compare the nested model against the global model.

\subsection{Annual mean Hg wet deposition}

Figure 2 shows the 2008-2009 annual mean Hg wet deposition flux over North America predicted by the global (upper panel) and nested (middle panel) models for the STD simulation. The eastern US is divided as MW (Midwest), NE (Northeast), ORV (Ohio River Valley and Mid-Atlantic), and SE (Southeast) as shown in Fig. 2. The spatial distribution of modeled wet deposition is the result of the combined variations of anthropogenic $\mathrm{Hg}$ (II) emissions, free tropospheric $\mathrm{Hg}$ (II) concentrations and precipitation. Although the global model and the nested model have very similar large scale patterns for wet deposition, the nested model resolves more de-
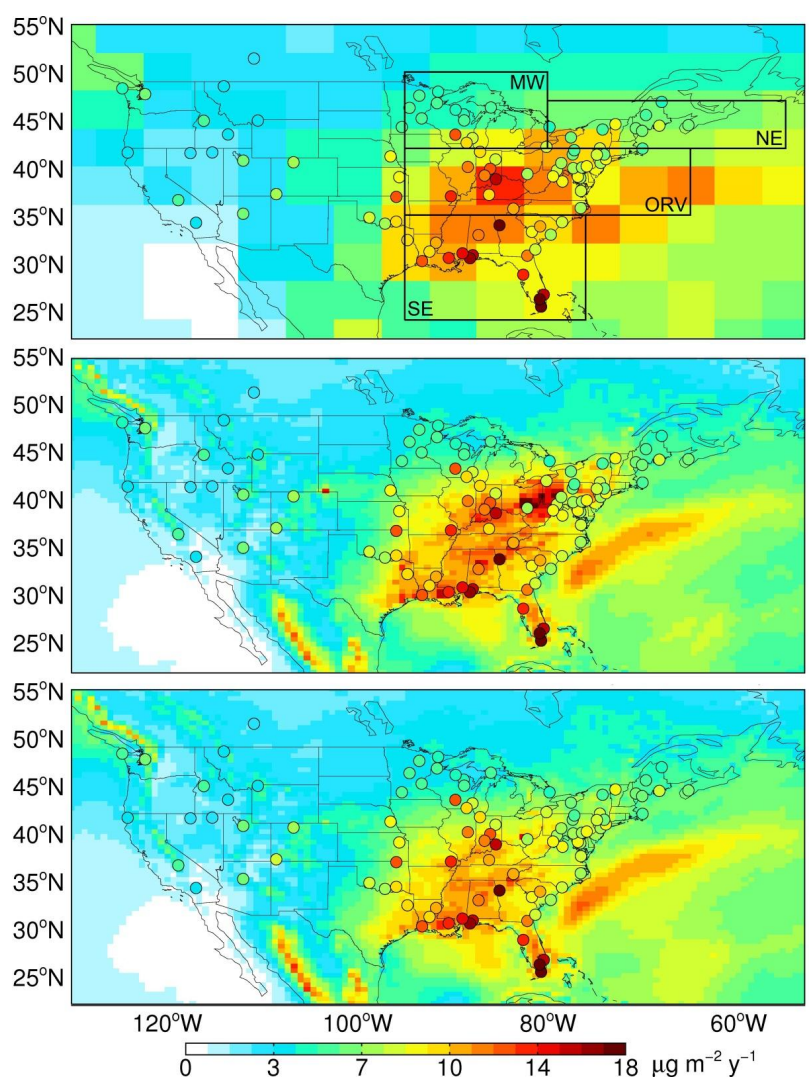

Fig. 2. Annual mean observed (circle) and simulated (background) Hg wet deposition flux for 2008-2009 over North America. Observations are from the Mercury Deposition Network (MDN). The three panels correspond to different GEOS-Chem Hg simulations: global STD model (top), nested STD simulation (middle), nested IPR simulation (bottom). The four regions considered in this study are indicated with black boxes in the top panel: Midwest (MW), Northeast (NE), Ohio River Valley (ORV), and Southeast (SE).

tail (Fig. 2). In the nested model, high wet deposition fluxes occur along the coastal regions of British Columbia, Washington and Mexico due to orographic precipitation; discrete high wet deposition flux is predicted over the Rocky Mountains following precipitation (Fig. 1). Higher spatial variability is also predicted by the nested model near point sources over the ORV and SE regions. For instance, the global model shows the highest wet deposition occurring over the grid box covering southern Indiana, Kentucky and southern Ohio. In contrast, the nested model shows elevated wet deposition flux concentrated over eastern Ohio and western Pennsylvania. Furthermore, the nested model displays more detail in land/ocean contrast in coastal regions (e.g. Florida and the western Gulf Coast), with enhanced deposition over land associated with scavenging of local emissions and enhanced precipitation. With this improvement, the nested model is able to reproduce the observed latitudal pattern for $\mathrm{Hg}$ wet deposition over the SE region - the deposition flux increases 
Table 1. Comparison of annual wet deposition fluxes (2008-2009) between MDN observations and the nested-grid GEOS-Chem model.

\begin{tabular}{lcrrrrr}
\hline Regions $^{\mathrm{a}}$ & \# of sites & \multicolumn{2}{c}{ Annual precipitation $\left(\mathrm{cm} \mathrm{yr}^{-1}\right)^{\mathrm{b}}$} & \multicolumn{2}{c}{ Annual Hg wet deposition flux $\left(\mu \mathrm{g} \mathrm{m}^{-2} \mathrm{yr}^{-1}\right)$} \\
\hline & & MDN & GEOS-5 & $\begin{array}{r}\text { MDN } \\
\text { Observations }\end{array}$ & $\begin{array}{r}\text { GEOS-Chem } \\
\text { STD simulation }\end{array}$ & $\begin{array}{r}\text { GEOS-Chem } \\
\text { IPR simulation }\end{array}$ \\
\hline MW & 19 & $6.2 \pm 2.6$ & $5.8 \pm 1.7$ & $7.0 \pm 4.8$ & $5.9 \pm 2.3(-14 \%$ c $)$ & $5.0 \pm 2.5(-27 \%)$ \\
NE & 10 & $9.9 \pm 1.7$ & $9.5 \pm 1.6$ & $6.8 \pm 3.0$ & $6.8 \pm 2.4(+2.6 \%)$ & $6.0 \pm 2.4(-9.0 \%)$ \\
ORV & 29 & $9.1 \pm 1.9$ & $9.3 \pm 1.8$ & $9.3 \pm 3.6$ & $11 \pm 4.5(+27 \%)$ & $8.8 \pm 3.8(-2.3 \%)$ \\
SE & 20 & $11 \pm 2.9$ & $10 \pm 5.2$ & $13 \pm 5.3$ & $11 \pm 5.4(-14 \%)$ & $10 \pm 5.2(-20 \%)$ \\
All sites & 95 & $8.1 \pm 1.3$ & $8.1 \pm 1.5$ & $8.8 \pm 3.6$ & $8.3 \pm 3.4(-3.4 \%)$ & $7.2 \pm 3.2(-16 \%)$ \\
\hline
\end{tabular}

The model is sampled at the location of the 95 sites selected.

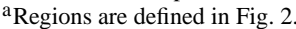

${ }^{\mathrm{b}}$ Mean and standard deviation of monthly averaged values.

${ }^{\mathrm{c}}$ The mean normalized bias, defined as the mean of $\frac{\text { model-observation }}{\text { observation }} \times 100$ is indicated in parentheses.

with lower latitude - a feature which is smoothed out by the coarse global model.

Figure 2 also displays $\mathrm{Hg}$ wet deposition flux measurements from the MDN network (circles). MDN sites collect weekly integrated precipitation samples and report $\mathrm{Hg}$ wet deposition flux and the $\mathrm{Hg}$ concentration in precipitation (MDN, 2011). Here we use the annual mean wet deposition flux for 2008-2009 at MDN sites with at least $75 \%$ of annual data availability ( 95 sites are selected). One issue with the samplers used by MDN is their low snow collection efficiency (Butler et al., 2008; Prestbo and Gay, 2009). Prestbo and Gay (2009) find that the MDN annual collection efficiency of precipitation is $87.1 \pm 6.5 \%$ at cold weather sites, but is unbiased at warm weather sites (efficiency $=$ $98.8 \pm 4.3 \%$ ). Lynch et al. (2003) summarized the 16 sites in Pennsylvania in 2002 and found the average collection efficiency was $89 \%$ in the cold period when snow and/or ice dominate precipitation. We correct for this bias in MDN weekly wet deposition by taking into account the fraction of precipitation falling as snow in the corresponding month and assuming an $89 \%$ collection efficiency of snow. The resulting annual wet deposition increases by $2 \%$ at sites in the NE and MW regions, with an $11 \%$ increase in winter. Wet deposition over the ORV and SE (where snow accounts for $11 \%$ and $<2 \%$ of annual precipitation, respectively) are nearly unaffected. All the MDN observations we show in this paper are corrected for this snow bias.

The standard nested-grid simulation captures the general spatial pattern of MDN wet deposition, especially the eastwest gradient and higher wet deposition flux over the SE region (Fig. 2). However, the standard model systematically overestimates the observed wet deposition flux over the ORV region. As shown in Table 1, the mean normalized model bias is $+27 \%$ in this region. For all $95 \mathrm{MDN}$ sites, the model displays a $-3.4 \%$ bias with a correlation coefficient $r=0.60$ (Fig. 3, left panel). The sites with the largest positive model bias are in ORV (blue circles), while negative model bias primarily occurs in the SE (orange circles) and the central and western US (denoted as OT, purple circles). Calculated re-

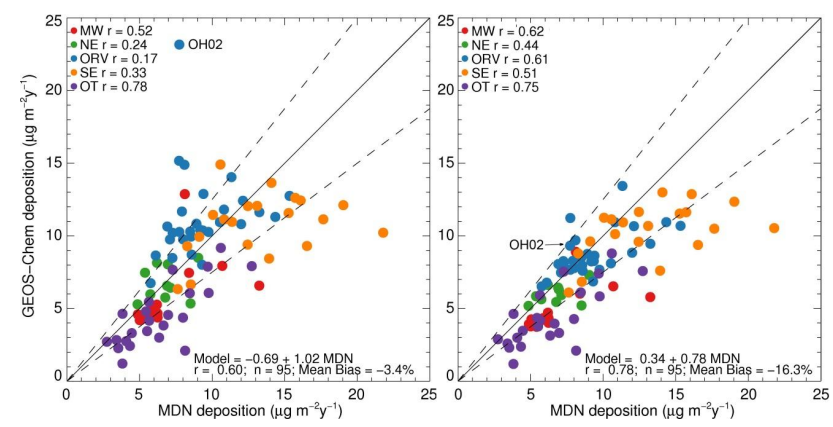

Fig. 3. Scatter plot of observed and modeled annual mean (20082009) $\mathrm{Hg}$ wet deposition flux. Left panel: standard nested-grid simulation; right panel: IPR nested-grid simulation. The solid line indicates the $1: 1$ line, while the dashed lines correspond to $\pm 25 \%$. The points are colored according to their geographic location as defined in Fig. 2 (OT corresponds to sites west of $95^{\circ} \mathrm{W}$ longitude). The correlation coefficient for each region as well as the overall regression statistics are also shown.

gionally, the correlation coefficients vary drastically, and are largest over the OT region ( $r=0.78$, Fig. 3), lowest in ORV $(r=0.17)$.

When we change the partitioning of anthropogenic $\mathrm{Hg}$ emissions in our IPR simulation (Sect. 2.2), the simulated $\mathrm{Hg}$ wet deposition flux in the ORV region decreases by $22 \%$ (Fig. 2, bottom panel). In particular for Athens, Ohio (OH02) the model bias decreases from $200 \%$ to $20 \%$ (Fig. 3). There are several major power plants located near this site that have a total of more than $0.5 \mathrm{Mg} \mathrm{a}^{-1} \mathrm{Hg}(\mathrm{II})$ emission in the corresponding $1 / 2 \times 2 / 3^{\circ}$ model grid (accounting for $3 \%$ of the total power plant $\mathrm{Hg}$ (II) emission of the US). Smaller decreases occur over the NE $(-11 \%)$, MW $(-16 \%)$, and SE $(-4.5 \%)$ regions, and nearly no change in the western and central US due to the smaller $\mathrm{Hg}$ contribution from anthropogenic emissions. The IPR simulation leads to improved agreement with MDN observations over the ORV region, with a decrease in the model bias from $+27 \%$ to $-2.3 \%$ (Table 1) accompanied by an increase in the correlation coefficient from 0.17 

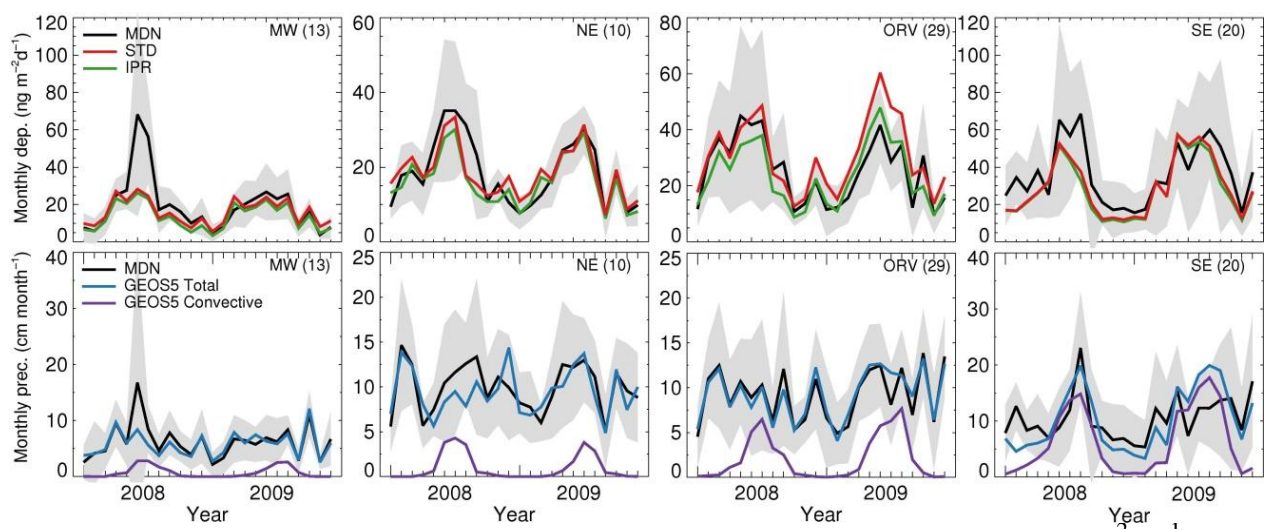

Fig. 4. Monthly mean variation in $\mathrm{Hg}$ wet deposition fluxes $\left(\mathrm{ng} \mathrm{m}^{-2} \mathrm{~d}^{-1}\right)$ and precipitation ( $\mathrm{cm} \mathrm{month}^{-1}$ ) during 2008-2009 for four regions over the eastern United States. Top row: MDN observations (black line, with shaded area indicating the standard error) are compared to the STD (red line) and the IPR (green line) nested simulations. Bottom row: surface precipitation observed at MDN sites is compared to total and convective GEOS-5 precipitation.

to 0.61 (Fig. 3). Over the MW, NE and SE regions the correlation coefficients improve, however the mean bias tends to worsen somewhat in the IPR simulation (MW from $-14 \%$ to $-27 \%$; NE from $+2.6 \%$ to $-9.0 \%$; SE from $-14 \%$ to $-20 \%$, Table 1). As discussed in Sect. 3.2 some of the low bias in the IPR simulation is associated with seasonal underestimates in precipitation for these regions. The overall correlation coefficient for all the MDN sites increases from $r=0.60$ to $r=0.78$. For $70 \%$ of the MDN sites, IPR model values are within $\pm 25 \%$ of observations. Assuming that inplume reduction occurs in CFPP plumes and does not occur in waste incinerators plumes results in a positive model bias of $+7.4 \%$ over the ORV region, only partially correcting the STD model overestimate.

Vijayaraghavan et al. (2008) conducted a more complex plume-in-grid modeling of the reduction of $\mathrm{Hg}$ (II) in CFPP plumes and found a 10-30\% reduction in wet deposition over the ORV region, partially correcting their overprediction of wet deposition in that region. Our results are consistent with this previous study.

\subsection{Seasonal variations in $\mathrm{Hg}$ wet deposition}

Figure 4 shows the comparison of modeled monthly $\mathrm{Hg}$ wet deposition flux and precipitation depth with MDN observations during 2008-2009. The observed $\mathrm{Hg}$ wet deposition flux has a strong seasonality in the eastern US, with a peak during summer and minimum during winter (Fig. 4, upper panels). The STD simulation generally captures this seasonality. The STD simulation overestimates observed mean $\mathrm{Hg}$ wet deposition over the ORV region (red line in Fig. 4, upper panels) especially in 2009, but this overestimate is largely mitigated in the IPR simulation (green line). The IPR simulation slightly underestimates the $\mathrm{Hg}$ wet deposition flux over ORV during 2008, but shows no bias in terms of two-year average (Table 1). The GEOS-5 meteorological fields repro- duce monthly precipitation observations in both the ORV and NE regions quite well (bottom panels in Fig. 4; Table 1). The low bias of the IPR simulation for the MW region is associated with a $60 \%$ underestimate of wet deposition during June and July 2008. This seems to be partially caused by an underestimate in precipitation during this time.

Over the SE, the IPR simulation underestimates MDN observations from August to October. While the model reproduces the high deposition rates observed over Louisiana, Mississippi, and Alabama, it does not reproduce the very high wet deposition rates $\left(10-12 \mu \mathrm{g} \mathrm{m}^{-2}\right.$ season $^{-1}$ ) observed at sites in Florida (Fig. 5). During summer, the model meteorological fields capture the observed high precipitation rates observed in the SE in $2008\left(15-20 \mathrm{~cm} \mathrm{month}^{-1}\right)$ due to convective precipitation, but overestimates summer 2009 precipitation. The high wet deposition rates in the SE, especially over Florida, have been attributed to deep convective scavenging from the free troposphere (Guentzel et al., 2001; Selin and Jacob, 2008). Thus the modeled low bias during late summer and autumn over Florida might be due to errors in the height of deep convection or to an underestimate of $\mathrm{Hg}$ (II) concentration in the tropical free atmosphere (Holmes et al., 2010).

Figure 5 shows the spatial distribution of the $\mathrm{Hg}$ wet deposition flux for each season. The IPR nested simulation and MDN observations are plotted separately. In winter (December, January, February (DJF)), the observed wet deposition flux is highest over the SE, in a region extending from Louisiana to Tennessee. Deposition rates increase in spring (March, April, May (MAM)) with high deposition areas extending northward to the MW. During summer (June, July, August (JJA)), wet deposition is very high along the Gulf Coast in a region covering eastern Texas to Florida, and further stretches to the NE. During autumn (September, October, November (SON)), the observed wet deposition 


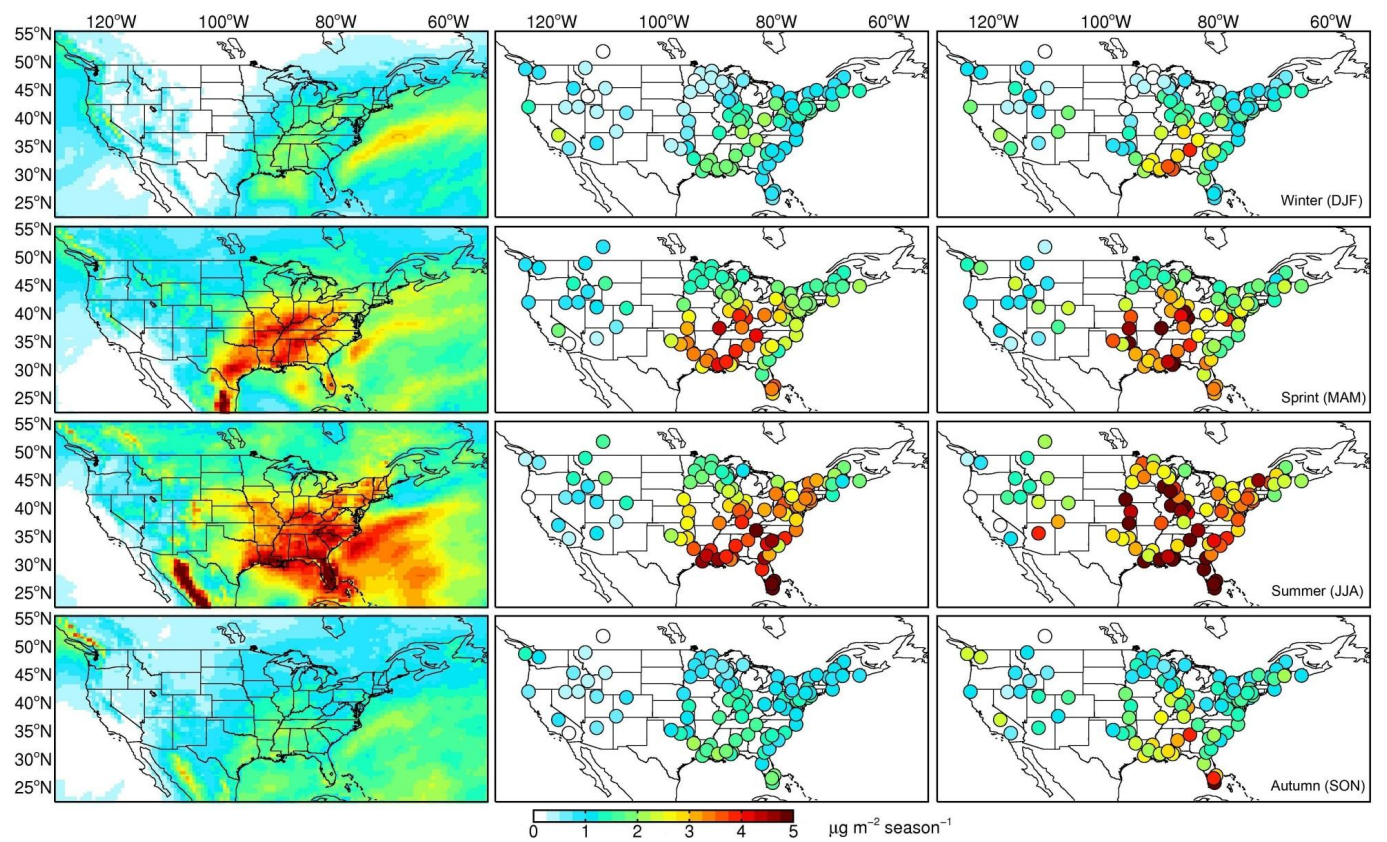

Fig. 5. Seasonal variations in the Hg wet deposition flux for 2008-2009. From top to bottom: winter (DJF), spring (MAM), summer (JJA), and autumn (SON). The first column shows the spatial distribution of the IPR nested-grid model wet deposition; the second column shows the model values extracted at MDN sites; the third column shows the observed wet deposition at MDN sites.

decreases again and has similar spatial distribution to that of winter. Generally, the nested model captures the seasonal change in the spatial pattern of wet deposition (Figs. 5 and 6). The correlation coefficient varies between $r=0.70$ (JJA) and $r=0.77$ (MAM). The IPR nested-grid simulation has the greatest predicting capacity over the eastern US during spring in terms of both low mean bias and correlation coefficient. During summer, the nested model captures the observed maximum high deposition fluxes over the SE, but underestimates MDN observations over the MW, as noted above. The nested model also underestimates the observed high deposition fluxes in SE in autumn and winter.

\subsection{Annual mean surface concentrations of atmospheric $\mathrm{Hg}$}

Figure 7 shows the annual mean TGM (defined as modeled $\mathrm{Hg}(0)+$ gas-phase $\mathrm{Hg}(\mathrm{II})$ ), reactive gaseous mercury (RGM, gas-phase $\mathrm{Hg}(\mathrm{II})$ ) and particulate-bound mercury (PBM, particulate-phase $\mathrm{Hg}(\mathrm{II})$ ) surface concentrations for the IPR Hg simulation in 2008-2009. The global and nested simulations show similar spatial distribution patterns for surface $\mathrm{Hg}$ concentrations following natural and anthropogenic $\mathrm{Hg}$ emissions. Highest TGM concentrations over the contiguous US are predicted over the ORV region (1.7-1.8 $\left.\mathrm{n} \mathrm{m}^{-3}\right)$, where a large number of power plants and waste incinerators are located. Slightly lower TGM concentrations (1.5$1.6 \mathrm{ng} \mathrm{m}^{-3}$ ) are modeled in Nevada and Utah where metal ore smelting plants and strong geogenic sources are lo-

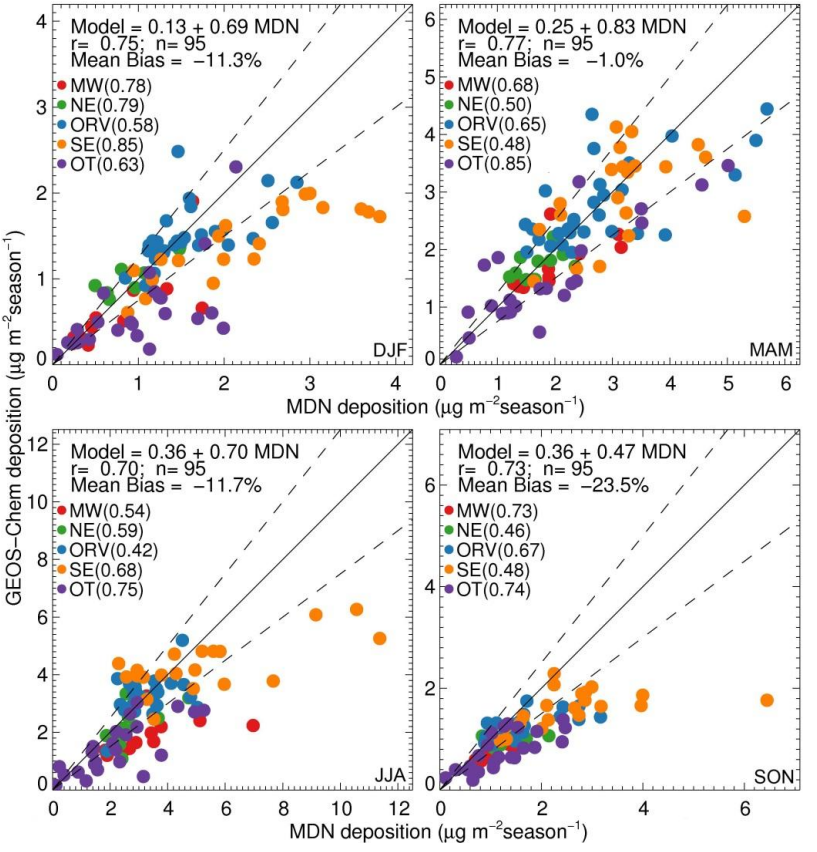

Fig. 6. Scatter plot of seasonal averaged (2008-2009) Hg wet deposition fluxes $\left(\mu \mathrm{g} \mathrm{m}^{-2}\right.$ season $^{-1}$ ) between IPR nested-grid simulation (vertical axis) and MDN observations (horizontal axis). Different colors denote sites in different regions as defined in Fig. 2, while OT corresponds to sites west of $95^{\circ} \mathrm{W}$ longitude. 

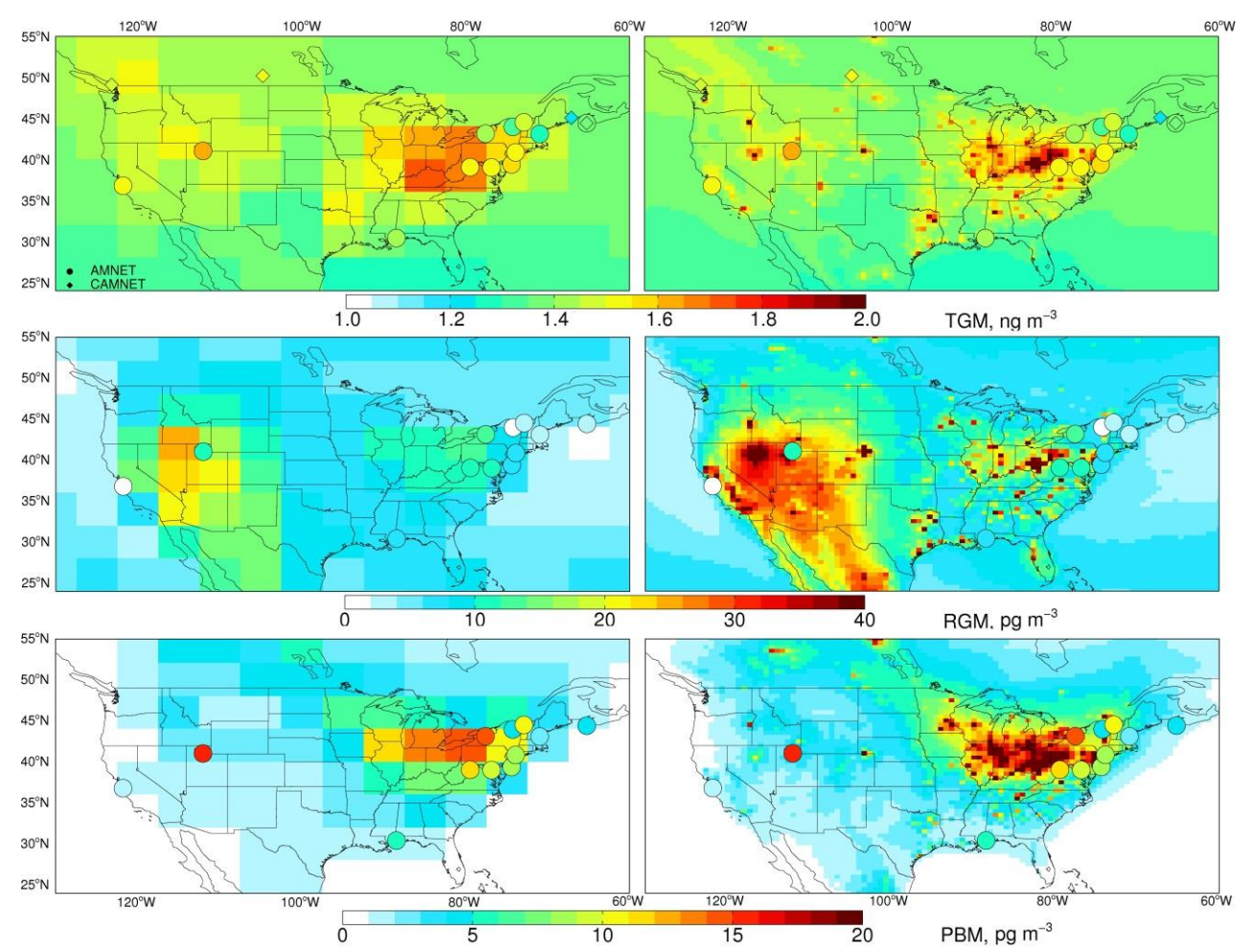

Fig. 7. Annual mean surface concentrations of TGM (top), RGM (middle) and PBM (bottom) during 2008-2009. Results from the global (left column) and nested (right column) IPR simulations are compared to observations from 14 AMNET sites (circles) and 5 CAMNET sites (diamonds). Two pairs of AMNet sites are collocated, so only 12 AMNet sites are identifiable.

cated (Gustin et al., 1997). Modeled TGM concentrations are lower $\left(1.3-1.5 \mathrm{ng} \mathrm{m}^{-3}\right.$ ) over the Great Plains region, southern Canada and northern Mexico, corresponding to typical Northern Hemisphere background concentrations (Slemr et al., 2011). The model predicts lower (1.3-1.4 $\mathrm{ng} \mathrm{m}^{-3}$ ) TGM concentrations in the marine boundary layer (MBL) because of faster oxidation of $\mathrm{Hg}(0)$ to $\mathrm{Hg}(\mathrm{II})$ in the MBL and subsequent deposition. These MBL concentrations are lower than cruise measurements over the Northern Atlantic Ocean (1.7$2.2 \mathrm{ng} \mathrm{m}^{-3}$ ) (Soerensen et al., 2010a), probably due to a model underestimate in ocean $\mathrm{Hg}(0)$ evasion (Soerensen et al., 2010b).

Compared with TGM, both RGM and PBM display stronger spatial variability due to their much shorter lifetimes. Following the anthropogenic emission pattern, RGM and PBM concentrations are enhanced over the ORV region $\left(10-20 \mathrm{pg} \mathrm{m}^{-3}\right)$, and are lowest in the region stretching across Southern Canada, the Great Plains, southern Canada and northern Mexico. The modeled RGM surface concentrations are highest over the West because of the subsidence of free tropospheric air (Selin and Jacob, 2008). The simulated PBM concentrations are low in this region because of the low particulate matter concentrations.

As expected, the nested model reveals much more spatial variability than the global model, especially near large point sources and over western North America. The average surface RGM and PBM concentrations in the nested model are $40 \%$ higher than in the global model. This is due to the stronger ventilation of surface air in the nested model (Wang et al., 2004), which more efficiently mixes $\mathrm{Hg}$ (II)rich free tropospheric air down to the surface. The global model averages the sub-grid vertical velocity (Wang et al., 2004) and suppresses subsidence of $\mathrm{Hg}$ (II) from higher altitude, where GEOS-Chem predicts high $\mathrm{Hg}$ (II) concentrations due to faster oxidation of $\operatorname{Hg}(0)$ at lower temperatures and lack of removal (Holmes et al., 2006, 2010).

We compare the model results to surface concentrations measured at 5 CAMNet sites and 14 AMNet sites (Figs. 7 and 8). CAMNet was established in 1996 and measures TGM across Canada using Tekran mercury vapor analyzers (Temme et al., 2007). AMNet is part of the National Atmospheric Deposition Program and currently consists of 20 sites (AMNET, 2009). Hg measurements are also conducted by Tekran instruments, and include $\mathrm{Hg}(0)$, RGM and $\mathrm{PBM}$ with a 2.5-micrometer impactor and $\mathrm{KCl}$-coated annular denuder (for ionic $\mathrm{Hg}$ ), thermally-desorbed particulate filter (for PBM), and gold traps (for $\mathrm{Hg}(0)$ ). To evaluate the model, we have selected 14 AMNet sites which are not influenced by large nearby sources (sites with $<2000 \mathrm{~kg} \mathrm{a}^{-1}$ anthropogenic $\mathrm{Hg}$ emissions within $100 \mathrm{~km}$ ). 
The nested IPR simulation reproduces the observed TGM annual mean concentrations at the 19 surface sites with no bias (obs.: $1.46 \pm 0.11 \mathrm{ng} \mathrm{m}^{-3}$, IPR model: $1.42 \pm 0.11 \mathrm{ng} \mathrm{m}^{-3}$ ). Observed PBM concentrations are wellcaptured by the IPR simulation (obs.: $7.8 \pm 4.2 \mathrm{pg} \mathrm{m}^{-3}$, IPR model: $8.8 \pm 6.7 \mathrm{pg} \mathrm{m}^{-3}$ ), however the model tends to overestimate observed RGM concentrations by a factor of 2.4 (obs.: $6.2 \pm 4.1 \mathrm{pg} \mathrm{m}^{-3}$, IPR model: $15 \pm 9.2 \mathrm{pg} \mathrm{m}^{-3}$ ). If we take into account the large variability $( \pm 70 \%)$ and high uncertainty (30-40\%) in RGM measurements (Aspmo et al., 2005; Lyman et al., 2007; Gustin and Jaffe, 2010) this degree of agreement is not unreasonable, especially since the model has some success at reproducing the seasonal cycle of RGM observations (see Sect. 3.4).

The nested IPR model shows higher correlation $(r=0.51$, 0.64 and 0.46 for TGM, RGM and PBM, respectively) with observations than does the global model ( $r=0.43,0.36$ and 0.39 , respectively). Indeed, for the NE region, where the number density of AMNet sites is highest, the nested model captures the north-south gradient much better than the global model, such as higher TGM concentrations in the Bronx (NY06, $1.52 \mathrm{ng} \mathrm{m}^{-3}$ ) than in upstate New York (NY43 and NY49, 1.42-1.33 $\mathrm{ng} \mathrm{m}^{-3}$ ).

The STD nested simulation predicts RGM and PBM concentrations that are twice as large as the IPR simulation, leading to a STD simulation overestimate of observations by a factor of 4 for RGM (obs.: $6.2 \pm 4.1 \mathrm{pg} \mathrm{m}^{-3}$, STD model: $26 \pm 24 \mathrm{pg} \mathrm{m}^{-3}$ ) and 2 for PBM (obs.: $7.8 \pm 4.2 \mathrm{pg} \mathrm{m}^{-3}$, STD model: $16 \pm 18 \mathrm{pg} \mathrm{m}^{-3}$ ). This indicates a high sensitivity of RGM and PBM concentrations to local $\mathrm{Hg}$ (II) emissions and shows that the AMNet RGM and PBM observations are consistent with rapid reduction of RGM in CFPP and waste incinerator plumes.

\subsection{Seasonal variation of surface $\mathrm{Hg}$ concentrations}

Figure 8 compares the seasonal cycle of observed and modeled TGM, RGM and PBM surface concentrations at AMNet and CAMNet sites. The observations at CAMNet sites are averaged over 2004-2007 (top four panels). For each AMNet site, the range of years with available observations is indicated in Fig. 8. The nested model results (STD: red line; IPR: green line) are averaged over 2008-2009.

The model closely matches the seasonal cycle of TGM at sites that are farthest from anthropogenic point sources. These include Kejimkujik, Burnt Island, NY20, VT99. At these sites, the seasonal cycle exhibits a summer minimum, which the model attributes to stronger summertime oxidation by $\mathrm{Br}$ atoms (Br concentrations peak in summer) and deposition (maximum in precipitation) (Holmes et al., 2010). This seasonal cycle was also reproduced by previous model studies assuming $\mathrm{OH} / \mathrm{O}_{3}$ as $\mathrm{Hg}(0)$ oxidants (Bergan and Rodhe, 2001; Selin et al., 2007). In these studies $\mathrm{OH}$ and $\mathrm{O}_{3}$ concentrations also peak in summer. Discrepancies between observations and models seem to occur when sites are af- fected by local sources (Kellerhals et al., 2003). For example, Chester, New Jersey (NJ32), Rochester, New York (NY43), and Antelope Island, Utah (UT96). The remote site in Kejimkujik, Nova Scotia shows a TGM maximum in June with a high standard deviation, indicating episodic influence by long range transport and/or fires.

The observed seasonal cycle for RGM varies from site to site. Most of the sites have a maximum during spring and a minimum during summer (e.g. MD08, NH06, NJ32, NS01, NY06, NY43, NY95 and VT99), while other sites (e.g. MS12, MS99 and UT96) show a maximum in summer. Similar site-to-site variability in the RGM seasonality was noted by Engle et al. (2010). These variations are likely caused by different combinations of the seasonality for oxidation, deposition, and subsidence of upper troposphere/lower stratospheric (UT/LS) air at these sites (Amos et al., 2012): oxidation is strongest in late spring, wet deposition is strongest during summer, and UT/LS influence maximizes in winter-spring. The IPR simulation captures the summer maximum of RGM at MS12 and UT96. However, it predicts little seasonality at the other sites and does not capture the spring peak observed at most of the sites. The reasons for this are unclear at this point, but could be associated with an underestimate of subsidence of RGM-rich air during spring.

PBM concentrations measured at AMNet sites show a seasonal maximum during the colder months, when $\mathrm{Hg}$ (II) would be expected to preferentially partition to aerosols (Rutter and Schauer, 2007; Amos et al., 2012). The IPR simulation captures this seasonality, especially at the sites in New Jersey, New York, and Vermont (NJ32, NY06, NY20, NY43, NY95, and VT99).

\subsection{Vertical and horizontal variations of TGM over California during ARCTAS}

Figure 9 shows the vertical distribution of TGM obtained in summer 2008 during the ARCTAS aircraft campaign (Jacob et al., 2010). We focus here on observations collected during flights over California and Nevada $\left(32-43^{\circ} \mathrm{N}, 114-\right.$ $125^{\circ} \mathrm{W}$ ), out of the Palmdale and Moffett Field (CA) airports. The measurements include $\operatorname{Hg}(0)$ and some fraction of $\mathrm{Hg}$ (II) due to uncertain inlet loss of $\mathrm{Hg}$ (II) (Holmes et al., 2010), so for comparison to the GEOS-Chem nested IPR simulation we show both the $\mathrm{Hg}(0)$ and TGM vertical profiles. We exclude episodic biomass burning plumes from the observations: $\mathrm{CO}>200 \mathrm{ppb}$ or $\mathrm{CH}_{3} \mathrm{CN}>0.25 \mathrm{ppt}$, following Holmes et al. (2010). The nested IPR simulation is sampled at the same time and altitude as the ARCTAS aircraft observations. The nested simulation reproduces the observed mean TGM concentration below $2 \mathrm{~km}$ altitude (1.1$1.3 \mathrm{ng} \mathrm{m}^{-3}$ ). At $2-5 \mathrm{~km}$ altitude, observations show a slight increase to $1.3 \mathrm{ng} \mathrm{m}^{-3}$, while above $7 \mathrm{~km}$ observations decrease to $\sim 1 \mathrm{ng} \mathrm{m}^{-3}$. These features are not captured by the model, which shows a relatively invariant vertical profile. 


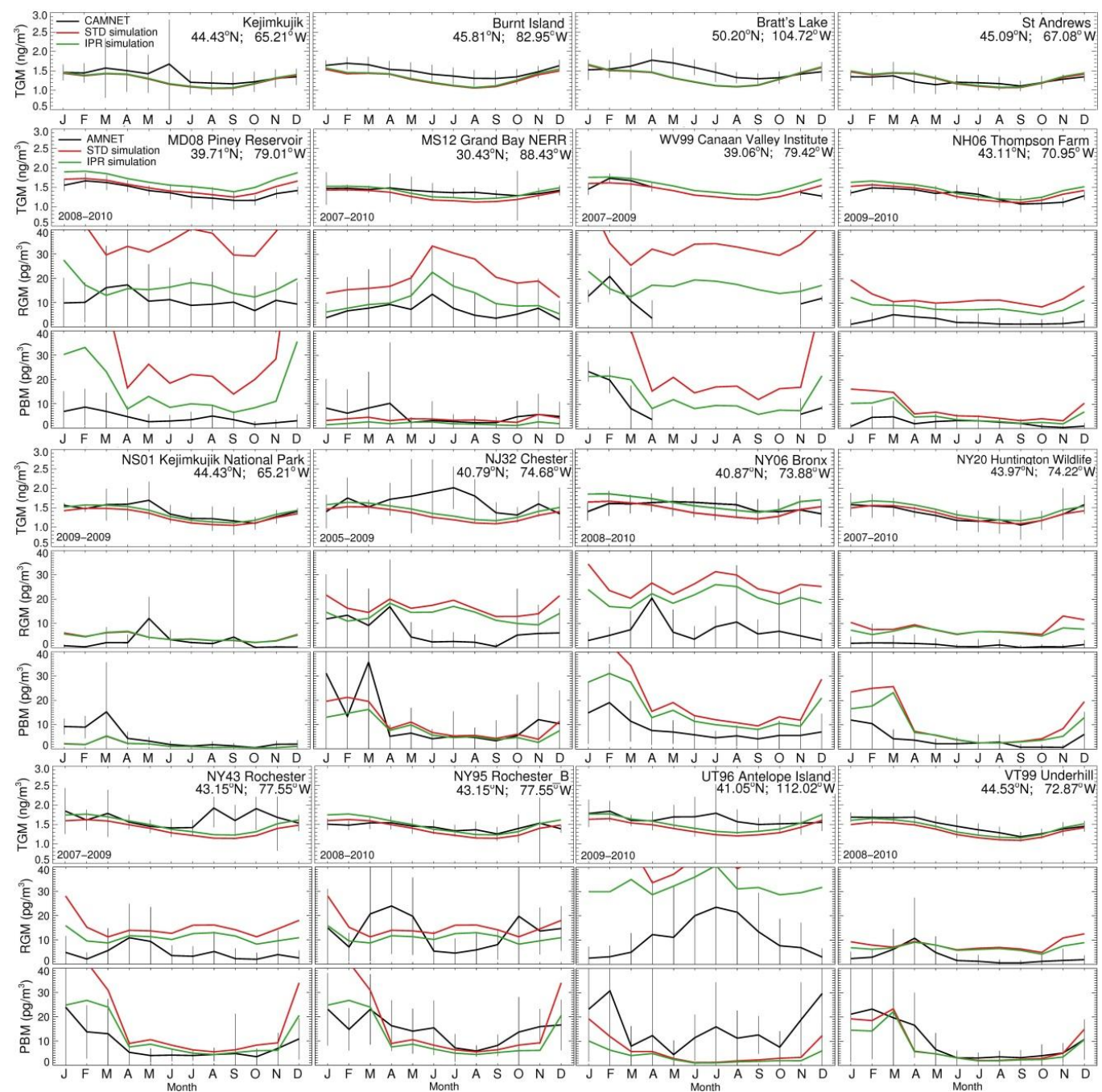

Fig. 8. Comparison of the monthly mean TGM, RGM and PBM concentrations observed at CAMNet and AMNet sites with the STD (red line) and IPR (green line) nested-grid GEOS-Chem simulations. The CAMNet sites are averaged over 2004-2007, while the AMNet sites observations are averaged during 2005-2010 when observation are available. The model results are averaged over 2008-2009. For the CAMNet sites (the 4 panels in the first row), only TGM observations are available.

Overall, the nested model shows no significant bias $(\mathrm{Hg}(0)$ : $1.16 \mathrm{ng} \mathrm{m}^{-3}$; TGM: $1.25 \mathrm{ng} \mathrm{m}^{-3}$ ) compared with observations $\left(1.21 \mathrm{ng} \mathrm{m}^{-3}\right)$.

The spatial distribution of observed TGM concentrations is displayed in Fig. 10. We show the modeled TGM concentrations from the global and nested IPR simulations for comparison. Because the model shows much smaller variability than the observations, we use different color scales and mainly focus on the relative spatial patterns. Although both the global and nested models have similar level of correlation with ARCTAS observations $(r=0.3)$, the nested model shows improved skill at capturing the spatial variability in observations. The nested model simulates localized enhancements in TGM over fires sampled in northern California (the branch with red color near $30-40^{\circ} \mathrm{N}$ and $122^{\circ} \mathrm{W}$ in the right panel). It also captures higher TGM concentrations due to anthropogenic emissions in southern California. The global model shows weaker and diluted enhancement of concentrations in these regions. Both the global and nested models miss the observed high concentration in western Nevada, which might be caused by a mix of mining activities and naturally Hg-enriched soils (Lyman and Gustin, 2008).

\subsection{Origin of Hg deposition over North America}

We conduct a sensitivity study where all anthropogenic $\mathrm{Hg}$ emissions over the US, Canada, and Mexico are turned off to separate the influence on deposition of regional anthropogenic $\mathrm{Hg}$ emissions from background emissions.

The two left panels in Fig. 11 show annual mean wet deposition over North America contributed by background 


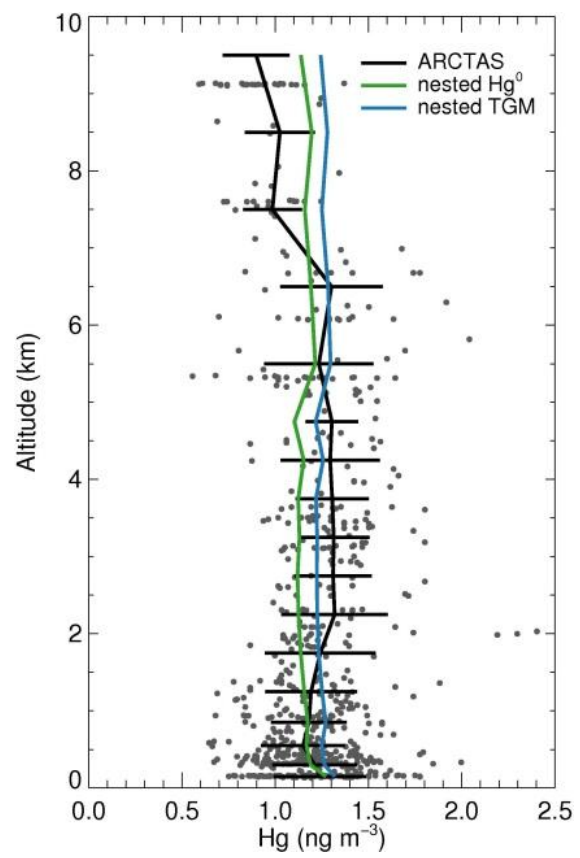

Fig. 9. Mean vertical profiles (black line) and standard deviations of TGM concentrations measured during the ARCTAS campaign over California and Nevada $\left(32-43^{\circ} \mathrm{N} ; 114-125^{\circ} \mathrm{W}\right)$ during summer 2008. Gray points correspond to individual TGM observations. The modeled vertical profile of $\mathrm{Hg}(0)$ from the nested IPR simulation is shown in green, while modeled TGM is in blue. The model is sampled at the time of observations along the flight track.

sources (natural sources over North America as well as natural + anthropogenic sources outside of North America) for the STD and IPR simulations. The model shows that these external sources lead to a maximum in wet deposition stretching from southern Texas to the NE, and there is also a maximum over Florida. The IPR simulation predicts slightly higher (5\%) background wet deposition compared to the STD simulation. Indeed the IPR simulation assumes a lower fraction of anthropogenic emissions as $\mathrm{Hg}$ (II), leading to less local deposition and increased export efficiency of anthropogenic emissions in the form of $\mathrm{Hg}(0)$ from regions outside of North America. Following transport on hemispheric scales, this additional background anthropogenic $\operatorname{Hg}(0)$ is oxidized to $\mathrm{Hg}$ (II) and leads to a small increase in background wet deposition flux over North America.

The contribution from anthropogenic North American $\mathrm{Hg}$ emissions is obtained by difference between this background simulation and simulations including anthropogenic emissions (central and right panels in Fig. 11). As expected, the assumed speciation of anthropogenic $\mathrm{Hg}$ emissions greatly affects our results. In the STD simulation, we find that North American anthropogenic sources account for $22 \%$ of the $\mathrm{Hg}$ wet deposition flux and $20 \%$ of the dry deposition flux in the contiguous United States (Table 2). The STD model shows that North American anthropogenic sources are responsible for large contributions in the industrial ORV, MW and NE ( $~ 30 \%$ of wet deposition), with the contributions near the borders between Ohio, Pennsylvania and West Virginia reaching up to $60 \%$ (Fig. 11). The modeled contribution from North America anthropogenic sources decreases gradually away from this region. In our IPR simulation we find that the contribution of anthropogenic North American emissions to wet deposition decreases by a factor of 2 relative to the STD simulation (Table 2): $10 \%$ of wet deposition and $13 \%$ of dry deposition in the contiguous US (compared to $22 \%$ and $20 \%$ in the STD simulation), reaching a maximum of $15 \%$ (wet) and $24 \%$ (dry) in the ORV region (compared to $32 \%$ and $41 \%$ in the STD simulation).

A similar diagnosis was done by Selin and Jacob (2008) with $\mathrm{OH} / \mathrm{O}_{3}$ as the main oxidants of $\mathrm{Hg}$ using GEOS-Chem at a spatial resolution of $4 \times 5^{\circ}$. They found the North American anthropogenic sources account for $27 \%$ and $17 \%$ for the wet and dry deposition fluxes over contiguous US, respectively. Seigneur et al. (2004) used the regional model TEAM at a resolution of $100 \mathrm{~km}$ and found North American emissions contributions to deposition to be $24 \%$ (wet) and $43 \%$ (dry). The results for wet deposition from both studies are similar to results from our STD simulation which assumes a high fraction of anthropogenic emissions as $\mathrm{Hg}(\mathrm{II})$. For example, Selin and Jacob (2008) assume anthropogenic emissions of $55 \mathrm{Mg} \mathrm{a}^{-1} \mathrm{Hg}(\mathrm{II})$ and $23 \mathrm{Mg} \mathrm{a}^{-1} \mathrm{Hg}(\mathrm{P})$ for the year 2000 over North America, similar to our STD emission inventory (59 $\mathrm{Mg} \mathrm{a}^{-1} \mathrm{Hg}(\mathrm{II})$ ). Seigneur et al. (2004) assume $72 \mathrm{Mg} \mathrm{a}^{-1} \mathrm{Hg}$ (II) and $13 \mathrm{Mg} \mathrm{a}^{-1} \mathrm{Hg}(\mathrm{P}$ ) (for years 19981999). Our IPR simulation assumes significantly lower emissions for $\mathrm{Hg}(\mathrm{II})\left(25 \mathrm{Mg} \mathrm{a}^{-1}\right)$, leading to a decrease in $\mathrm{Hg}$ deposition near point sources, and thus a decrease in their contribution to the deposition flux over the contiguous US. This implies that the domestic contribution diagnosed by this approach is highly sensitive to the large uncertainties associated with anthropogenic $\mathrm{Hg}$ emission speciation and in-plume reduction processes. Given the improved agreement of our IPR simulation with observations of wet deposition (Sects. 3.1 and 3.2), RGM and PBM (Sect. 3.4), our $12 \%$ estimate of the North American anthropogenic contribution to deposition appears to be most consistent with observations.

Compared to the model results of Selin and Jacob (2008) our results differ in the spatial distribution of background sources' contribution to wet deposition. Selin and Jacob (2008) calculated a maximum wet deposition flux over southern Texas of $18-20 \mu \mathrm{g} \mathrm{m}^{-2}$, nearly twice as large as our $10-12 \mu \mathrm{g} \mathrm{m}^{-2}$. Compared to $\mathrm{Br}$ atom oxidation, the $\mathrm{OH} / \mathrm{O}_{3}$ chemistry shifts wet deposition to tropical regions with elevated $\mathrm{OH}$ concentrations (Holmes et al., 2010). Convective precipitation in the GEOS-4 meteorological fields is stronger than in the GEOS-5 fields. In addition, the updates for $\mathrm{Hg}$ wet deposition implemented by Wang et al. (2011) and Amos et al. (2012) could also influence the spatial distribution of $\mathrm{Hg}$ wet deposition flux. 

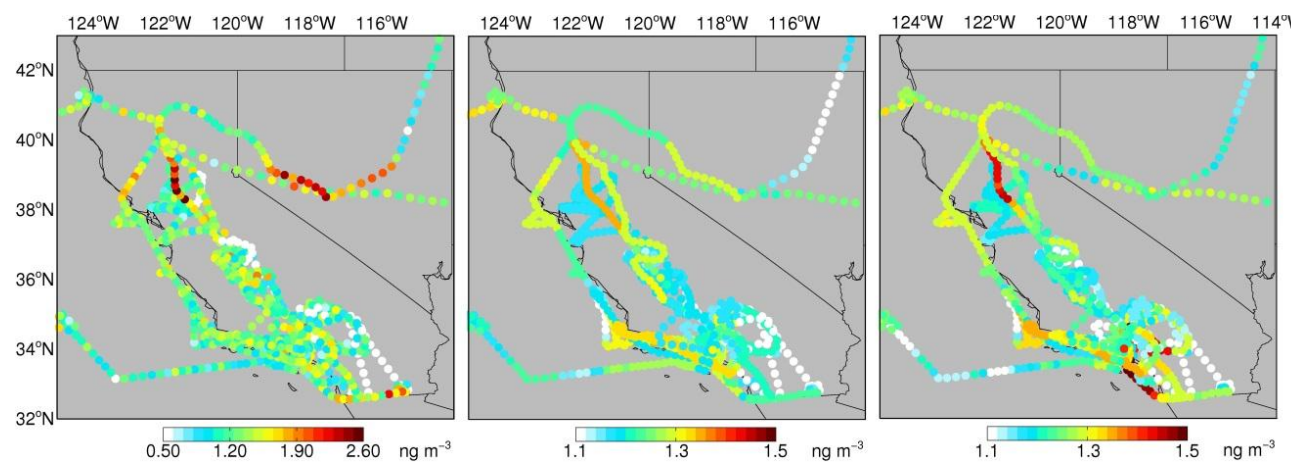

Fig. 10. Observed TGM concentrations during the ARCTAS aircraft campaign (left). The TGM concentrations predicted by the global (middle) and nested (right) IPR simulations sampled along the flight track are also shown. Note that the observation and model results have different color scales.

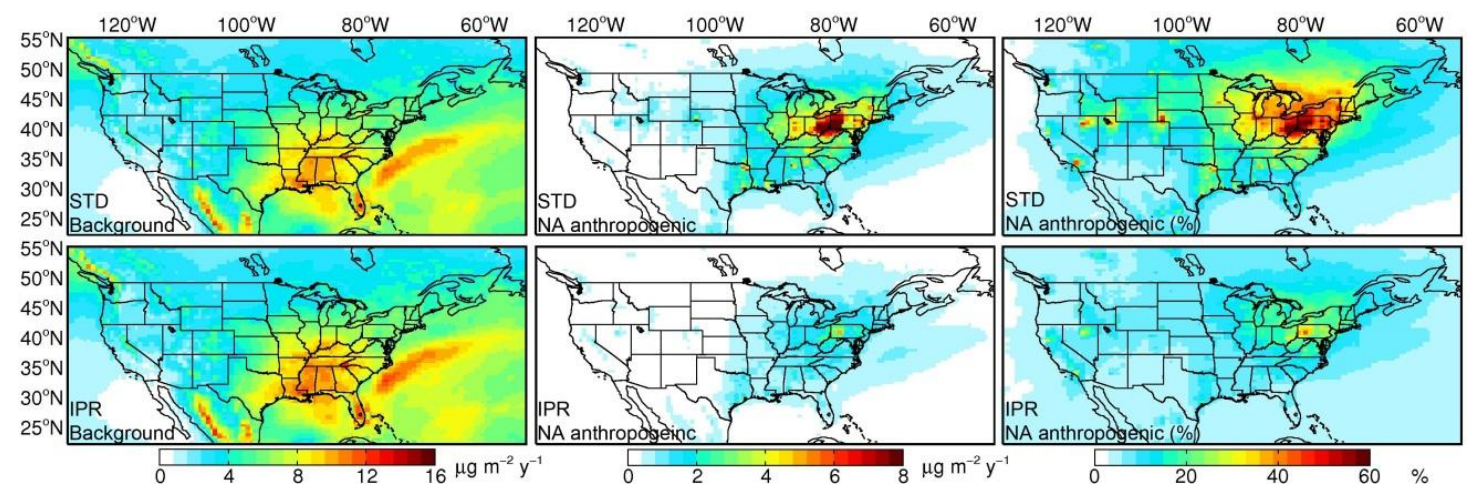

Fig. 11. Contributions of global background and North American anthropogenic emissions to wet deposition during 2008-2009. Top row (STD simulation): absolute wet deposition fluxes due to global background (left) and North American anthropogenic sources (middle), and the percent contribution by North American anthropogenic sources (right). The bottom three panels are for the IPR simulation.

Many studies have tried to estimate the contribution of local sources to wet deposition, either using surface observations or models. In general, estimates that relied on observations result in higher contributions than estimated by models. Keeler et al. (2006) attributed $\sim 70 \%$ of $\mathrm{Hg}$ wet deposition at Steubenville, Ohio to coal combustion. In a later study, White et al. (2009) found an enhancement of up to $72 \%$ of $\mathrm{Hg}$ concentration in precipitation at sites within $1 \mathrm{~km}$ of power plants during episodic events, and $42 \%$ when averaged over the whole summer season. Similar studies conducted in the Chicago/Gary urban area show that sites less than $100 \mathrm{~km}$ apart differed in volume-weighted mean $\mathrm{Hg}$ concentration by over 30\% (Lin and Pehkonen, 1999). The volume-weighted mean $\mathrm{Hg}$ concentration measured in urban sites in Detroit was also $25-35 \%$ higher than those measured in a rural site $\sim 60 \mathrm{~km}$ east (Gildemiester, 2001). The short lifetimes of $\mathrm{Hg}$ (II) lead to strong spatial variance near point sources at a spatial scale of $1-10 \mathrm{~km}$, which cannot be captured in our GEOS-Chem nested grid simulation with a $\sim 50 \mathrm{~km}$ horizontal resolution. As most of the MDN and AMNet sites used in our study are not directly downwind of large point sources, they should represent regional levels of $\mathrm{Hg}$ (II) concentrations and wet deposition. Similarly, the GEOS-Chem model results evaluated at those sites should thus be representative over regional scales, but likely underestimate the anthropogenic contribution at very small local scales.

\section{Conclusions}

We have developed a nested Hg simulation in the GEOSChem chemical transport model, with a horizontal resolution of $1 / 2^{\circ}$ latitude by $2 / 3^{\circ}$ longitude over North America. Boundary conditions are provided by a global GEOS-Chem $\mathrm{Hg}$ simulation at $4 \times 5^{\circ}$ resolution using the same emissions, chemistry, deposition, and meteorological fields as the nested model.

We have updated the anthropogenic $\mathrm{Hg}$ emission in the US and Canada using the EPA's National Emissions Inventory and the Canadian National Pollutant Release Inventory, both for 2005. The resulting anthropogenic $\mathrm{Hg}$ emissions in North America are $87 \mathrm{Mg} \mathrm{a}^{-1} \mathrm{Hg}(0)$ and $59 \mathrm{Mg} \mathrm{a}^{-1} \mathrm{Hg}(\mathrm{II})$. While these inventories assume that a significant fraction of 
Table 2. Contribution from North American $\mathrm{Hg}$ anthropogenic sources to wet and dry deposition (2008-2009).

\begin{tabular}{llll}
\hline \multirow{2}{*}{ Regions } & $\begin{array}{l}\text { GEOS-Chem } \\
\text { STD simulation }\end{array}$ & $\begin{array}{l}\text { GEOS-Chem } \\
\text { IPR simulation }\end{array}$ \\
\hline \multirow{2}{*}{ MW } & Wet & $31 \%$ & $15 \%$ \\
& Dry & $21 \%$ & $14 \%$ \\
& Total & $\mathbf{2 4} \%$ & $\mathbf{1 4} \%$ \\
\hline \multirow{2}{*}{ NE } & Wet & $32 \%$ & $16 \%$ \\
& Dry & $18 \%$ & $12 \%$ \\
& Total & $\mathbf{2 3} \%$ & $\mathbf{1 3 \%}$ \\
\hline \multirow{2}{*}{ ORV } & Wet & $32 \%$ & $15 \%$ \\
& Dry & $41 \%$ & $24 \%$ \\
& Total & $\mathbf{3 9} \%$ & $\mathbf{2 2} \%$ \\
\hline \multirow{2}{*}{ SE } & Wet & $16 \%$ & $8 \%$ \\
& Dry & $25 \%$ & $16 \%$ \\
& Total & $\mathbf{2 3} \%$ & $\mathbf{1 3 \%}$ \\
\hline \multirow{2}{*}{ Contiguous } & Wet & $22 \%$ & $10 \%$ \\
& Dry & $20 \%$ & $13 \%$ \\
& Total & $\mathbf{2 1 \%}$ & $\mathbf{1 2} \%$ \\
\hline
\end{tabular}

anthropogenic emissions are emitted as $\mathrm{Hg}(\mathrm{II})$, observations in power plant plumes suggest that most of this $\mathrm{Hg}$ (II) is quickly reduced to $\mathrm{Hg}(0)$ directly downwind. We therefore conduct a sensitivity simulation where we change the anthropogenic $\mathrm{Hg}$ speciation profile over North America to yield $121 \mathrm{Mg} \mathrm{a}^{-1} \mathrm{Hg}(0)$ and $25 \mathrm{Mg} \mathrm{a}^{-1} \mathrm{Hg}(\mathrm{II})$. We contrast results from this in-plume reduction (IPR) simulation to our standard (STD) simulation.

Relative to the global model, the nested-grid model shows improved skill at capturing the high spatial and temporal variability of $\mathrm{Hg}$ wet deposition observed at MDN sites in 2008-2009. However, the STD nested model simulation shows a systematic $27 \%$ overestimate in $\mathrm{Hg}$ wet deposition over the Ohio River Valley (ORV), a region with high emissions from coal-fired power plants. Changing the speciation of anthropogenic emissions in our IPR simulation reduces this model bias to $-2 \%$ over the ORV region, and improves the model performance over North America. The IPR simulation also captures the spatial patterns of wet deposition as a function of season, with high wet deposition fluxes concentrated in the SE during spring and extending towards the NE during summer. The IPR simulation shows a $60 \%$ underestimate in wet deposition over the MW in the summer of 2008 , which is associated with a $50 \%$ underestimate in precipitation. While the model reproduces the high deposition rates observed in the SE in Louisiana, Mississippi, and Alabama, it does not reproduce the very high wet deposition rates (10-12 $\mu \mathrm{g} \mathrm{m}^{-2} /$ season) observed at sites in Florida during summer.

The nested IPR simulation reproduces the observed annual mean and seasonal variations in surface concentrations of TGM, RGM and PBM observed at 5 CAMNet sites and 14 AMNet sites. The nested model reproduces the horizontal variability in observations better than the global model, because it better resolves the influence of local anthropogenic sources. The nested IPR model shows no bias for TGM and PBM, but is a factor of 2.4 too high relative to RGM observations. In contrast, the STD simulation leads to a factor of 4 overestimate in observed RGM and a factor of 2 overestimate in PBM. This may be further evidence for rapid in-plume reduction of RGM. The nested model captures the overall horizontal variability in TGM concentrations observed over California during the ARCTAS campaign, but displays a reduced dynamic range compared to observations.

By conducting a sensitivity study without North American anthropogenic $\mathrm{Hg}$ emissions, we assess the relative contribution of regional anthropogenic emissions on deposition. Our results are highly sensitive to the assumed speciation of anthropogenic emissions. In the IPR simulation, the North American anthropogenic sources contribute only $10 \%$ of the total $\mathrm{Hg}$ wet deposition in the US, compared to $22 \%$ in the STD simulation. The modeled IPR percent contribution varies from $4 \%$ in the western US to $16 \%$ in the eastern US (32\% in the STD simulation). The modeled percent contribution can be as high as $60 \%$ near some large point emission sources. The IPR mean modeled contribution of North American anthropogenic emissions to dry deposition is $13 \%$ ( $20 \%$ in the STD simulation), increasing to $24 \%$ in the Ohio River Valley (41\% in the STD simulation). Given the improved agreement with wet deposition, RGM, and PBM observations obtained in the IPR simulation, our lower estimate of North American contribution to deposition (12\%) appears to be more robust.

Acknowledgements. This work was supported by funding from EPRI under contract EP-35343/C16024. We thank EPRI program manager Leonard Levin for his support during this study. We would like to acknowledge and thank all the site operators for the CAMNet, AMNet, and MDN networks.

Edited by: A. Dastoor

\section{References}

AMNet: NADP's Atmospheric Mercury Network: Moving toward Total Mercury Deposition, National Atmospheric Deposition Program, Illinois State Water Survey, Champaign, IL (http:// nadp.sws.uiuc.edu/amn/), 2009.

Amos, H. M., Jacob, D. J., Holmes, C. D., Fisher, J. A., Wang, Q., Yantosca, R. M., Corbitt, E. S., Galarneau, E., Rutter, A. P., Gustin, M. S., Steffen, A., Schauer, J. J., Graydon, J. A., Louis, V. L. St., Talbot, R. W., Edgerton, E. S., Zhang, Y., and Sunderland, E. M.: Gas-particle partitioning of atmospheric $\mathrm{Hg}$ (II) and its effect on global mercury deposition, Atmos. Chem. Phys., 12, 591-603, doi:10.5194/acp-12-591-2012, 2012. 
Aspmo, K., Gauchard, P., Steffen, A., Temme, C., Berg, T., Bahlmann, E., Banic, C., Dommergue, A., Ebinghaus, R., and Ferrari, C.: Measurements of atmospheric mercury species during an international study of mercury depletion events at $\mathrm{Ny}$ Ålesund, Svalbard, spring 2003. How reproducible are our present methods?, Atmos. Environ., 39, 7607-7619, 2005.

Balabanov, N. B., Shepler, B. C., and Peterson, K. A.: Accurate global potential energy surface and reaction dynamics for the ground state of $\mathrm{HgBr} 2$, J. Phys. Chem. A, 109, 8765-8773, 2005.

Bash, J. O.: Description and initial simulation of a dynamic bidirectional air-surface exchange model for mercury in Community Multiscale Air Quality (CMAQ) model, J. Geophy. Res., 115, D0635, doi:10.1029/2009JD012834, 2010.

Bergan, T. and Rodhe, H.: Oxidation of elemental mercury in the atmosphere; Constraints imposed by global scale modelling, J. Atmos. Chem., 40, 191-212, 2001.

Bey, I., Jacob, D. J., Yantosca, R. M., Logan, J. A., Field, B. D., Fiore, A. M., Li, Q. B., Liu, H. G. Y., Mickley, L. J., and Schultz, M. G.: Global modeling of tropospheric chemistry with assimilated meteorology: Model description and evaluation, J. Geophys. Res., 106, 23073-23095, 2001.

Bullock, O. R., Atkinson, D., Braverman, T., Civerolo, K., Dastoor, A., Davignon, D., Ku, J.-Y., Lohman, K., Myers, T. C., Park, R. J., Seigneur, C., Selin, N. E., Sistla, G., and Vijayaraghavan, K.: The North American Mercury Model Intercomparison Study (NAMMIS): Study description and model-to-model comparisons, J. Geophys. Res., 113, D17310, doi:10.1029/2008JD009803, 2008.

Bullock, O. R., Atkinson, D., Braverman, T., Civerolo, K., Dastoor, A., Davignon, D., Ku, J. Y., Lohman, K., Myers, T. C., Park, R. J., Seigneur, C., Selin, N. E., Sistla, G., and Vijayaraghavan, K.: An analysis of simulated wet deposition of mercury from the North American Mercury Model Intercomparison Study, J. Geophys. Res., 114, D08301, doi:10.1029/2008jd011224, 2009.

Butler, T. J., Cohen, M. D., Vermeylen, F. M., Likens, G. E., Schmeltz, D., and Artz, R. S.: Regional precipitation mercury trends in the eastern USA, 1998-2005: Declines in the Northeast and Midwest, no trend in the Southeast, Atmos. Environ., 42, 1582-1592, 2008.

Calvert, J. G. and Lindberg, S. E.: Mechanisms of mercury removal by $\mathrm{O}-3$ and $\mathrm{OH}$ in the atmosphere, Atmos. Environ., 39, 33553367, 2005.

CAMNet, Canadian Atmospheric Mercury Measurement Network: Environment Canada, available at: http://www.msc.ec.gc. ca/arqp/camnet_e.cfm, 2011.

Chen, D., Wang, Y., McElroy, M. B., He, K., Yantosca, R. M., and Le Sager, P.: Regional CO pollution and export in China simulated by the high-resolution nested-grid GEOS-Chem model, Atmos. Chem. Phys., 9, 3825-3839, doi:10.5194/acp-9-3825-2009, 2009.

Dastoor, A. and Larocque, Y.: Global circulation of atmospheric mercury: a modelling study, Atmos. Environ., 38, 147-161, 2004.

Donohoue, D. L., Bauer, D., Cossairt, B., and Hynes, A. J.: Temperature and pressure dependent rate coefficients for the reaction of $\mathrm{Hg}$ with $\mathrm{Br}$ and the reaction of $\mathrm{Br}$ with $\mathrm{Br}$ : A pulsed laser photolysis-pulsed laser induced fluorescence study, J. Phys. Chem. A, 110, 6623-6632, 2006.
Dvonch, J. T., Keeler, G. J., and Marsik, F. J.: The influence of meteorological conditions on the wet deposition of mercury in southern Florida, J. Appl. Meteorol., 44, 1421-1435, 2005.

Edgerton, E. S., Hartsell, B. E., and Jansen, J. J.: Mercury speciation in coal-fired power plant plumes observed at three surface sites in the southeastern US, Environ. Sci. Technol., 40, 4563-4570, 2006.

Engle, M. A., Tate, M. T., Krabbenhoft, D. P., Schauer, J. J., Kolker, A., Shanley, J. B., and Bothner, M. H.: Comparison of atmospheric mercury speciation and deposition at nine sites across central and eastern North America, J. Geophys. Res., 115, 13, D18306, doi:10.1029/2010jd014064, 2010.

Fiore, A. M., Horowitz, L. W., Purves, D. W., Levy, H., Evans, M. J., Wang, Y. X., Li, Q. B., and Yantosca, R. M.: Evaluating the contribution of changes in isoprene emissions to surface ozone trends over the eastern United States, J. Geophys. Res., 110, D12303, doi:10.1029/2004JD005485, 2005.

Gårdfeldt, K., Sommar, J., Strömberg, D., and Feng, X.: Oxidation of atomic mercury by hydroxyl radicals and photoinduced decomposition of methylmercury in the aqueous phase, Atmos. Environ., 35, 3039-3047, 2001.

Gildemiester, A. E.: Urban atmospheric mercury, Ph. D., University of Michigan, Ann Arbor, 2001.

Goodsite, M. E., Plane, J. M. C., and Skov, H.: A theoretical study of the oxidation of $\mathrm{Hg}-0$ to $\mathrm{HgBr} 2$ in the troposphere, Environ. Sci. Technol., 38, 1772-1776, 2004.

Graydon, J. A., Louis, V. L. S., Hintelmann, H., Lindberg, S. E., Sandilands, K. A., Rudd, J. W. M., Kelly, C. A., Hall, B. D., and Mowat, L. D.: Long-term wet and dry deposition of total and methyl mercury in the remote boreal ecoregion of Canada, Environ. Sci. Technol., 42, 8345-8351, doi:10.1021/es801056j, 2008.

Guentzel, J. L., Landing, W. M., Gill, G. A., and Pollman, C. D.: Processes influencing rainfall deposition of mercury in Florida, Environ. Sci. Technol., 35, 863-873, 2001.

Gustin, M. and Jaffe, D. A.: Reducing the uncertainty in measurement and understanding of mercury in the atmosphere, Environ. Sci. Technol., 44, 2222-2227, 2010.

Gustin, M. S., Taylor Jr., G. E., and Maxey, R. A.: Effect of temperature and air movement on the flux of elemental mercury from substrate to the atmosphere, J. Geophys. Res., 102, 3891-3898, 1997.

Holmes, C. D., Jacob, D. J., and Yang, X.: Global lifetime of elemental mercury against oxidation by atomic bromine in the free troposphere, Geophys. Res. Lett., 33, L20808, doi:10.1029/2006GL027176, 2006.

Holmes, C. D., Jacob, D. J., Mason, R. P., and Jaffe, D. A.: Sources and deposition of reactive gaseous mercury in the marine atmosphere, Atmos. Environ., 43, 2278-2285, 2009.

Holmes, C. D., Jacob, D. J., Corbitt, E. S., Mao, J., Yang, X., Talbot, R., and Slemr, F.: Global atmospheric model for mercury including oxidation by bromine atoms, Atmos. Chem. Phys., 10, 12037-12057, doi:10.5194/acp-10-12037-2010, 2010.

Hynes, A., Donohoue, D., Goodsite, M., Hedgecock, I., Pirrone, N., and Mason, R.: Our current understanding of major chemical and physical processes affecting mercury dynamics in the atmosphere and at air-water/terrestrial interfaces, in: Mercury Fate and Transport in the Global Atmosphere, edited by: Pirrone, N. and Mason, R. P., chap. 14, Springer, 2009. 
Jacob, D. J., Crawford, J. H., Maring, H., Clarke, A. D., Dibb, J. E., Emmons, L. K., Ferrare, R. A., Hostetler, C. A., Russell, P. B., Singh, H. B., Thompson, A. M., Shaw, G. E., McCauley, E., Pederson, J. R., and Fisher, J. A.: The Arctic Research of the Composition of the Troposphere from Aircraft and Satellites (ARCTAS) mission: design, execution, and first results, Atmos. Chem. Phys., 10, 5191-5212, doi:10.5194/acp-10-5191-2010, 2010.

Keeler, G. J., Landis, M. S., Norris, G. A., Christianson, E. M., and Dvonch, J. T.: Sources of mercury wet deposition in eastern Ohio, USA, Environ. Sci. Technol., 40, 5874-5881, 2006.

Kellerhals, M., Beauchamp, S., Belzer, W., Blanchard, P., Froude, F., Harvey, B., McDonald, K., Pilote, M., Poissant, L., Puckett, K., Schroeder, B., Steffen, A., and Tordon, R.: Temporal and spatial variability of total gaseous mercury in Canada: results from the Canadian Atmospheric Mercury Measurement Network (CAMNet), Atmos. Environ., 37, 1003-1011, 2003.

Li, Q. B., Jacob, D. J., Park, R., Wang, Y. X., Heald, C. L., Hudman, R., Yantosca, R. M., Martin, R. V., and Evans, M.: North American pollution outflow and the trapping of convectively lifted pollution by upper-level anticyclone, J. Geophys. Res., 110, D10301, doi:10.1029/2004JD005039, 2005.

Lin, C. J. and Pehkonen, S. O.: The chemistry of atmospheric mercury: a review, Atmos. Environ., 33, 2067-2079, 1999.

Lin, X. and Tao, Y.: A numerical modelling study on regional mercury budget for eastern North America, Atmos. Chem. Phys., 3, 535-548, doi:10.5194/acp-3-535-2003, 2003.

Lindberg, S., Bullock, R., Ebinghaus, R., Engstrom, D., Feng, X. B., Fitzgerald, W., Pirrone, N., Prestbo, E., and Seigneur, C.: A Synthesis of Progress and Uncertainties in Attributing the Sources of Mercury in Deposition, Ambio, 36, 19-32, 2007.

Liu, H., Jacob, D., Bey, I., and Yantosca, R. M.: Constraints from $\mathrm{Pb} 210$ and $\mathrm{Be} 7$ on wet deposition and transport in a global threedimensional chemical tracer model driven by assimilated meteorological fields, J. Geophys. Res., 106, 12109-12128, 2001.

Lohman, K., Seigneur, C., Edgerton, E., and Jansen, J.: Modeling mercury in power plant plumes, Environ. Sci. Technol., 40, 3848-3854, 2006.

Lyman, S. N. and Gustin, M. S.: Speciation of atmospheric mercury at two sites in northern Nevada, USA, Atmos. Environ., 42, $927-$ 939, 2008

Lyman, S. N. and Gustin, M. S.: Determinants of atmospheric mercury concentrations in Reno, Nevada, USA, Sci. Total Environ., 408, 431-438, doi:10.1016/j.scitotenv.2009.09.045, 2009.

Lyman, S. N., Gustin, M. S., Prestbo, E. M., and Marsik, F. J.: Estimation of dry deposition of atmospheric mercury in Nevada by direct and indirect methods, Environ. Sci. Technol., 41, 19701976, 2007.

Lynch, J. A., Horner, K. S., and Grimm, J. W.: Atmospheric deposition: spatial and temporal variations in Pennsylvania 2002, Penn State Institutes of the Environment, The Pennsylvania State University, University Park, PA, 2003.

Mao, H., Talbot, R. W., Sive, B. C., Youn Kim, S., Blake, D. R., and Weinheimer, A. J.: Arctic mercury depletion and its quantitative link with halogens, J. Atmos. Chem., 65, 145-170, 2011.

Mason, R. A.: Mercury emissions from natural processes and their importance in the global mercury cycle, in: Mercury fate and transport in the global atmosphere: emissions, measurements and models, edited by: Pirrone, N. and Mason, R. A., Springer, Dordrecht Heidelberg London New York, 173-191, 2009.
MDN, National Atmospheric Deposition Program, Mercury Deposition Network Information, available at: http://nadp.sws.uiuc. edu/mdn/ (last access: October 2011), 2011.

Mergler, D., Anderson, H. A., Chan, L. H. M., Mahaffey, K. R., Murray, M., Sakamoto, M., and Stern, A. H.: Methylmercury exposure and health effects in humans: A worldwide concern, Ambio, 36, 3-11, 2007.

Morel, F. M., Kraepiel, A. M. L., and Amyot, M.: The chemical cycle and bioaccumulation of mercury, Annu. Rev. Ecol. Syst., 29, 543-566, 1998.

Pacyna, E. G., Pacyna, J. M., Sundseth, K., Munthe, J., Kindbom, K., Wilson, S., Steenhuisen, F., and Maxson, P.: Global emission of mercury to the atmosphere from anthropogenic sources in 2005 and projections to 2020, Atmos. Environ., 44, 2487-2499, 2010.

Pan, L., Chai, T. F., Carmichael, G. R., Tang, Y. H., Streets, D., Woo, J. H., Friedli, H. R., and Radke, L. F.: Top-down estimate of mercury emissions in China using four-dimensional variational data assimilation, Atmos. Environ., 41, 2804-2819, 2007.

Park, R. J., Jacob, D. J., Kumar, N., and Yantosca, R. M.: Regional visibility statistics in the United States: Natural and transboundary pollution influences, and implications for the Regional Haze Rule, Atmos. Environ., 40, 5405-5423, 2006.

Pirrone, N., Cinnirella, S., Feng, X., Finkelman, R., Friedli, H., Leaner, J., Mason, R., Mukherjee, A., Stracher, G., Streets, D., and Telmer, K.: Global Mercury Emissions to the Atmosphere from Natural and Anthropogenic Sources, in: Mercury Fate and Transport in the Global Atmosphere, edited by: Mason, R. and Pirrone, N., 1-47, Springer US, 2009.

Pongprueksa, P., Lin, C.-J., Lindberg, S. E., Jang, C., Braverman, T., Jr., O. R. B., Ho, T. C., and Chu, H.-W.: Scientific uncertainties in atmospheric mercury models III: Boundary and initial conditions, model grid resolution, and $\mathrm{Hg}(\mathrm{II})$ reduction mechanism, Atmos. Environ., 42, 1828-1845, 2008.

Prestbo, E. M. and Gay, D. A.: Wet deposition of mercury in the US and Canada, 1996-2005: Results and analysis of the NADP mercury deposition network (MDN), Atmos. Environ., 43, 42234233, 2009.

Psomopoulos, C. S., Bourka, A., and Themelis, N. J.: Waste-toenergy: A review of the status and benefits in USA, Waste Management, 29, 1718-1724, 2009.

Richter, A., Wittrock, F., Ladstatter-Weissenmayer, A., and Burrows, J.: GOME measurements of stratospheric and tropospheric BrO, Adv. Space Res., 29, 1667-1672, 2002.

Rutter, A. P. and Schauer, J. J.: The effect of temperature on the gasparticle partitioning of reactive mercury in atmospheric aerosols, Atmos. Environ., 41, 8647-8657, 2007.

Seigneur, C., Karamchandani, P., Lohman, K., Vijayaraghavan, K., and Shia, R. L.: Multiscale modeling of the atmospheric fate and transport of mercury, J. Geophys. Res., 106, 27795-27809, 2001.

Seigneur, C., Vijayaraghavan, K., Lohman, K., Karamchandani, P., and Scott, C.: Global source attribution for mercury deposition in the United States, Environ. Sci. Technol., 38, 555-569, 2004.

Selin, N. E. and Jacob, D. J.: Seasonal and spatial patterns of mercury wet deposition in the United States: Constraints on the contribution from North American anthropogenic sources, Atmos. Environ., 42, 5193-5204, 2008.

Selin, N. E., Jacob, D. J., Park, R. J., Yantosca, R. M., Strode, S., Jaegle, L., and Jaffe, D.: Chemical cycling and deposition of 
atmospheric mercury: Global constraints from observations, J. Geophys. Res., 112, D02308, doi:10.1029/2006jd007450, 2007.

Selin, N. E., Jacob, D. J., Yantosca, R. M., Strode, S., Jaegle, L., and Sunderland, E. M.: Global 3-D land-ocean-atmosphere model for mercury: Present-day versus preindustrial cycles and anthropogenic enrichment factors for deposition, Global Biogeochem. Cy., 22, GB2011, doi:10.1029/2007gb003040, 2008.

Shia, R. L., Seigneur, C., Pai, P., Ko, M., and Sze, N. D.: Global simulation of atmospheric mercury concentrations and deposition fluxes, J. Geophys. Res., 104, 23747-23760, 1999.

Si, L. and Ariya, P. A.: Reduction of oxidized mercury species by dicarboxylic acids (C-2-C-4): Kinetic and product studies, Environ. Sci. Technol., 42, 5150-5155, 2008.

Sigler, J. M., Mao, H., and Talbot, R.: Gaseous elemental and reactive mercury in Southern New Hampshire, Atmos. Chem. Phys., 9, 1929-1942, doi:10.5194/acp-9-1929-2009, 2009.

Simpson, W. R., Carlson, D., Hönninger, G., Douglas, T. A., Sturm, M., Perovich, D., and Platt, U.: First-year sea-ice contact predicts bromine monoxide $(\mathrm{BrO})$ levels at Barrow, Alaska better than potential frost flower contact, Atmos. Chem. Phys., 7, 621-627, doi:10.5194/acp-7-621-2007, 2007.

Sioris, C. E., Kovalenko, L. J., McLinden, C. A., Salawitch, R. J., Roozendael, M. V., Goutail, F., Dorf, M., Pfeilsticker, K., Chance, K., von Savigny, C., Liu, X., Kurosu, T. P., Pommereau, J. P., Boesch, H., and Frerick, J.: Latitudinal and vertical distribution of bromine monoxide in the lower stratosphere from Scanning Imaging Absorption Spectrometer for Atmospheric Chartography limb scattering measurements, J. Geophys. Res., 111, D14301, doi:10.1029/2005JD006479, 2006.

Slemr, F., Brunke, E.-G., Ebinghaus, R., and Kuss, J.: Worldwide trend of atmospheric mercury since 1995, Atmos. Chem. Phys., 11, 4779-4787, doi:10.5194/acp-11-4779-2011, 2011.

Soerensen, A. L., Skov, H., Jacob, D. J., Soerensen, B. T., and Johnson, M. S.: Global concentrations of gaseous elemental mercury and reactive gaseous mercury in the marine boundatry layer, Environ. Sci. Technol., 44, 7425-7430, 2010a.

Soerensen, A. L., Sunderland, E. M., Holmes, C. D., Jacob, D. J., Yantosca, R. M., Skov, H., Christensen, J. H., Strode, S. A., and Mason, R. P.: An Improved Global Model for Air-Sea Exchange of Mercury: High Concentrations over the North Atlantic, Environ. Sci. Technol., 44, 8574-8580, 2010 b.

Steffen, A., Douglas, T., Amyot, M., Ariya, P., Aspmo, K., Berg, T., Bottenheim, J., Brooks, S., Cobbett, F., Dastoor, A., Dommergue, A., Ebinghaus, R., Ferrari, C., Gardfeldt, K., Goodsite, M. E., Lean, D., Poulain, A. J., Scherz, C., Skov, H., Sommar, J., and Temme, C.: A synthesis of atmospheric mercury depletion event chemistry in the atmosphere and snow, Atmos. Chem. Phys., 8, 1445-1482, doi:10.5194/acp-8-1445-2008, 2008.

Stevenson, W.: Emissions from large MWC units at MACT compliance. Memorandum to Docket A-90-45, US EPA, Research Triangle Park, NC, 2002.

Strahan, S. E., Duncan, B. N., and Hoor, P.: Observationally derived transport diagnostics for the lowermost stratosphere and their application to the GMI chemistry and transport model, Atmos. Chem. Phys., 7, 2435-2445, doi:10.5194/acp-7-2435-2007, 2007.

Streets, D. G., Zhang, Q., and Wu, Y.: Projections of global mercury emissions in 2050, Environ. Sci. Technol., 43, 2983-2988, 2009.
Strode, S. A., Jaeglé, L., Selin, N. E., Jacob, D. J., Park, R. J., Yantosca, R. M., Mason, R. P., and Slemr, F.: Air-sea exchange in the global mercury cycle, Global Biogeochem. Cy., 21, GB1017, doi:10.1029/2006GB002766, 2007.

Sunderland, E. M.: Mercury exposure from domestic and imported estuarine and marine fish in the U.S. seafood market, Environ. Health Perspect., 115, 235-242, 2007.

Temme, C., Blanchard, P., Steffen, A., Banic, C., Beauchamp, S., Poissant, L., Tordon, R., and Wiens, B.: Trend, seasonal and multivariate analysis study of total gaseous mercury data from the Canadian atmospheric mercury measurement network (CAMNet), Atmos. Environ., 41, 5423-5441, 2007.

ter Schure, A., Caffrey, J., Gustin, M., Holmes, C., Hynes, A., Landing, B., Landis, M., Laudel, D., Levin, L., Nair, U., Jansen, J., Ryan, J., Walters, J., Schauer, J., Volkamer, R., Waters, D., and Weiss, P.: An integrated approach to assess elevated mercury wet deposition and concentrations in the southeastern United States, 10th International Conference on Mercury as Global Pollutant, Halifax, Nova Scotia, Canada, 2011.

UNEP, United Nations Environment Programme: http: //www.unep.org/hazardoussubstances/Mercury/Negotiations/ tabid/3320/Default.aspx (last access: June 2012), 2012.

Vijayaraghavan, K., Karamchandani, P., Seigneur, C., Balmori, R., and Chen, S.-Y.: Plume-in-grid modeling of atmospheric mercury, J. Geophys. Res., 113, D24305, doi:10.1029/2008jd010580, 2008.

Wang, Q., Jacob, D. J., Fisher, J. A., Mao, J., Leibensperger, E. M., Carouge, C. C., Le Sager, P., Kondo, Y., Jimenez, J. L., Cubison, M. J., and Doherty, S. J.: Sources of carbonaceous aerosols and deposited black carbon in the Arctic in winter-spring: implications for radiative forcing, Atmos. Chem. Phys., 11, 1245312473, doi:10.5194/acp-11-12453-2011, 2011.

Wang, Y. X., McElroy, M. B., Wang, T., and Palmer, P. I.: Asian emissions of $\mathrm{CO}$ and NOx: Constraints from aircraft and Chinese station data, J. Geophys. Res., 109, D24304, doi:10.1029/2004JD005250, 2004a.

Wang, Y. X., McElroy, M. B., Jacob, D. J., and Yantosca, R. M.: A nested grid formulation for chemical transport over Asia: Applications to CO, J. Geophys. Res., 109, D22307, doi:10.1029/2004jd005237, 2004b.

Weiss-Penzias, P. S., Gustin, M. S., and Lyman, S. N.: Sources of gaseous oxideized mercury and mercury dry deposition at two southeastern U.S. sites, Atmos. Environ., 45, 4569-4579, 2011.

Wesely, M. L.: Parameterization of surface resistances to gaseous dry deposition in regional-scale numerical-models, Atmos. Environ., 23, 1293-1304, 1989.

White, E. M., Keeler, G. J., and Landis, M. S.: Spatial variability of mercury wet deposition in eastern Ohio: summertime meteorological case study analysis of local source influences, Environ. Sci. Technol., 43, 4946-4953, 2009.

Yang, X., Cox, R. A., Warwick, N. J., Pyle, J. A., Carver, G. D., O'Connor, F. M., and Savage, N. H.: Tropospheric bromine chemistry and its impacts on ozone: A model study, J. Geophys. Res., 110, D23311, doi:10.1029/2005JD006244, 2005. 